\title{
Evaluation of a Novel Mitochondrial Pan-Mucorales Marker for the Detection, Identification, Quantification, and Growth Stage Determination of Mucormycetes
}

\author{
Rita Caramalho ${ }^{1,+}$, Lisa Madl ${ }^{1,+}$, Katharina Rosam ${ }^{1}{ }^{1}$, Günter Rambach ${ }^{1}$, Cornelia Speth ${ }^{1}$, \\ Johannes Pallua ${ }^{2}$, Thomas Larentis ${ }^{1}$, Ricardo Araujo 3,4 ${ }^{\mathbb{D}}$, Ana Alastruey-Izquierdo ${ }^{5}$ (D), \\ Cornelia Lass-Flörl ${ }^{1}$ (D) and Michaela Lackner ${ }^{1, *(\mathbb{D})}$ \\ 1 Institute of Hygiene and Medical Microbiology, Medical University of Innsbruck, Schöpfstraße 41, \\ 6020 Innsbruck, Austria; rita.dinora@hotmail.com (R.C.); lisa.madl@hotmail.com (L.M.); \\ katharina.rosam@i-med.ac.at (K.R.); Guenter.Rambach@i-med.ac.at (G.R.); Cornelia.Speth@i-med.ac.at (C.S.); \\ thomas.larentis@rolmail.net (T.L.); Cornelia.lass-floerl@i-med.ac.at (C.L.-F.) \\ 2 Institute of Pathology, Neuropathology and Molecular Pathology, Medical University of Innsbruck, \\ Müllerstraße 44, 6020 Innsbruck, Austria; Johannes.Pallua@i-med.ac.at \\ 3 i3 S, Instituto de Investigacao e Inovacao da Universidade do Porto, R. Alfredo Allen, \\ 4200-135 Porto, Portugal; ricjparaujo@yahoo.com \\ 4 Department of Medical Biotechnology, School of Health Sciences, Flinders University, Sturt Rd, \\ Bedford Park SA 5042, Australia \\ 5 Mycology Reference Laboratory, National Centre for Microbiology. Instituto de Salud Carlos III. \\ Majadahonda, 28220 Madrid, Spain; anaalastruey@isciii.es \\ * Correspondence: Michaela.Lackner@i-med.ac.at; +43-512-9003-70725 \\ + These authors contributed equally to the paper.
}

Received: 20 August 2019; Accepted: 8 October 2019; Published: 11 October 2019

\begin{abstract}
Mucormycosis infections are infrequent yet aggressive and serious fungal infections. Early diagnosis of mucormycosis and its discrimination from other fungal infections is required for targeted treatment and more favorable patient outcomes. The majority of the molecular assays use $18 \mathrm{~S}$ rDNA. In the current study, we aimed to explore the potential of the mitochondrial $\mathrm{rnl}$ (encoding for large-subunit-ribosomal-RNA) gene as a novel molecular marker suitable for research and diagnostics. Rnl was evaluated as a marker for: (1) the Mucorales family, (2) species identification (Rhizopus arrhizus, R. microsporus, Mucor circinelloides, and Lichtheimia species complexes), (3) growth stage, and (4) quantification. Sensitivity, specificity, discriminatory power, the limit of detection (LoD), and cross-reactivity were evaluated. Assays were tested using pure cultures, spiked clinical samples, murine organs, and human paraffin-embedded-tissue (FFPE) samples. Mitochondrial markers were found to be superior to nuclear markers for degraded samples. Rnl outperformed the UMD universal ${ }^{\circledR}$ (Molyzm) marker in FFPE (71.5\% positive samples versus 50\%). Spiked blood samples highlighted the potential of rnl as a pan-Mucorales screening test. Fungal burden was reproducibly quantified in murine organs using standard curves. Identification of pure cultures gave a perfect $(100 \%)$ correlation with the detected internal transcribed spacer (ITS) sequence. In conclusion, mitochondrial genes, such as rnl, provide an alternative to the nuclear $18 \mathrm{~S}$ rDNA genes and deserve further evaluation.
\end{abstract}

Keywords: mucormycosis; HRM; qPCR; large subunit ribosomal DNA; mitochondrial genes; growth stage; activity marker; seminested PCR; pan-Mucorales 


\section{Introduction}

The order Mucorales is assigned to the subphylum Mucoromycotina, one of the most ancient, early divergent groups of fungi [1]. In recent decades, the incidence of mucormycosis has increased due to: (a) a growing population of immunocompromised patients [2], (b) increased awareness [3], (c) the impact of mold-active prophylaxis [4], and (d) increasing numbers of patients with uncontrolled diabetes mellitus [5].

Until now, Mucorales have been identified using primarily histological and standard mycological methods, as well as DNA sequencing of the internal transcribed spacer (ITS) region [6]. These gold standard approaches are time-consuming and can be performed only for well-established infections. In contrast, molecular diagnostic tools can facilitate early diagnosis and screening. In medical mycology, a combination of real-time polymerase chain reactions (PCRs) and antigen-enzyme-linked immunosorbent assays (ELISAs) are used to supplement classical culture- and microscopy-based detection of pathogens in clinical specimens [7].

Discrimination of mucormycetes from other fungal agents is required for treatment decisions and patient management. Recent advances in the molecular diagnostics of mucormycetes have been comprehensively reviewed by Millon et al. [5], but key challenges such as standardization remain unmet [8]. The identification of pure cultures using matrix-assisted laser desorption ionization-time-of-flight mass spectrometry (MALDI-TOF MS) [9], plus the development of a novel pan-fungal antigen assay that detects a disaccharide in serum (MS-DS) and covers mucormycetes, are important developments [10]. Recent steps towards a pan-Mucorales marker system have included the use of real-time PCR with partial cytochrome $B$ [11] as a template and a pan-Mucorales PCR that detects the spore coating protein $(\mathrm{CotH})$ gene in urine samples [12,13]. Apart from these two examples that illustrate how pan-Mucorales detection can use alternative gene regions and markers, real-time PCR assays still use nuclear ribosomal DNA target (18 S, $28 \mathrm{~S}$, and the internal transcribed spacer (ITS)) regions [14]. These ribosomal markers appear to be less useful for the design of pan-Mucorales markers because of a poor specificity at the order level. The potential of non-nuclear markers has yet to be to be evaluated.

Mitochondrial genes have long contributed to forensicscience [15]. Mitochondrial DNA is protected from degradation (possibly due to the mitochondria's double membrane), is stable across multiple generations (due to absence of meiosis or genetic recombination events), and exists in higher copies numbers than nuclear DNA [16]. These properties have encouraged evaluation of mitochondrial genes as diagnostic markers in mucormycetes.

Mucormycetes are hard to detect in clinical specimens (particularly biopsies) and their non-septate hyphae make quantification difficult in murine experiments [17]. Hyphae break easily during sample preparation and their leaked DNA is susceptible to degradation by host DNAses. In contrast, the high copy number and the degradation resistance of mtDNA [16] should confer increased marker sensitivity. Moreover, normalization of mitochondrial genes with a nuclear housekeeping gene should enable differentiation between resting and active fungal stages. This would be particularly useful for the interpretation of murine studies by enabling discrimination between colonization (i.e., presence of conidia) and infection (i.e., presence of hyphae) in respiratory tract samples.

This study aimed to assess the potential of a mitochondrial gene marker (rnl) for a broad range of diagnostic and research applications. The rnl gene was tested as a marker for the following applications: (a) pan-Mucorales identification in paraffin-embedded tissues, (b) pan-Mucorales identification marker in whole blood samples, (c) Mucorales quantification in murine organs, (d) growth stage determination, and (e) identification of Mucorales in pure cultures.

\section{Materials and Methods}

\subsection{Strain Collection and Cultivation}

The Mucorales strain sets used to evaluate the performance of the rnl marker given in Tables S1 and S2 were characterized in a previous study [18]. Fungal stocks stored in $0.9 \%$ sodium chloride 
at $-20^{\circ} \mathrm{C}$ served as inoculum sources. Fungi were grown on supplemented minimal medium (SUP) agar [19] at $37^{\circ} \mathrm{C}$, with the exception of Mucor spp., which were grown at $30^{\circ} \mathrm{C}$ and further incubated for 3-5 days. Mycelia were harvested in $0.9 \%$ sodium chloride. Conidia were separated using a $40 \mu \mathrm{m}$ nylon cell strainer (VWR ${ }^{\circledR}$, Belgium). Identification (ID) at the genus level was performed by visualization of microscopic (Olympus CX21 microscope; Olympus, USA) and macroscopic (Axioplan microscope; Zeiss, Germany) characteristics. Species ID was obtained by direct sequencing of the internal transcribed spacer (ITS) [20] with slightly modified primers [18]. Genomic DNA was extracted [21] and ITS sequences were identified using the pairwise sequence alignment tool of the central bureau schimmelcultures (CBS) Knaw database (http://www.cbs.knaw.nl/Collections).

\section{2. rnl Marker Design}

The discriminatory power of the mitochondrial rnl gene was evaluated in silico using reference mitochondrial genomes of three Mucorales species: Rhizopus arrhizus, Lichtheimia hongkongensis (syn. Lichtheimia ramosa), and Mucor circinelloides f. lusitanicus (GenBank AY863212.1, KJ561171.1 and KR809877.1) (Figure 1). Universal primers for amplification and sequencing, rnl_fw (5'-GCGAAATACCTTGGCCACTA-3'), and rnl_rv (5'-CCGGCTTATGCCATTACACT-3') were designed using Geneious ${ }^{\mathrm{TM}}$ software v. 8.1.9 (Biomatters Limited, Auckland, NZ) to give a DNA fragment amplified from positions $1925 \mathrm{bp}$ to $2314 \mathrm{bp}$ of the R. arrhizus rnl gene (GenBank AY863212.1). The PCR reaction mixture $(10 \mu \mathrm{L})$ contained $300 \mathrm{nM}$ of each primer, $5 \mu \mathrm{L}$ of KAPA2 $\mathrm{G}$ Robust HotStart ReadyMix ${ }^{\mathrm{TM}}$ (KAPA Biosystems, Boston, Massachusetts, USA), $3 \mu \mathrm{L}$ of ultrapure water, and $1 \mu \mathrm{L}$ of genomic DNA (10-20 ng/ $\mu \mathrm{L})$. PCR amplification used a peqSTAR $2 \times$ gradient thermal cycler (PEQLAB biotechnology, Erlangen, Germany) programmed as follows: initial cycle $95.0{ }^{\circ} \mathrm{C} / 2 \mathrm{~min}$, followed by 30 cycles at $95.0{ }^{\circ} \mathrm{C} / 15 \mathrm{~s}, 57.0^{\circ} \mathrm{C} / 30 \mathrm{~s}, 72.0{ }^{\circ} \mathrm{C} / 1 \mathrm{~min}$, and a final cycle at $72.0^{\circ} \mathrm{C} / 3 \mathrm{~min}$. PCR amplicon sizes ranged from $367 \mathrm{bp}$ (for R. arrhizus) to $391 \mathrm{bp}$ (for L. ramosa and M. circinelloides). DNA sequence analysis of the PCR products used the BigDye ${ }^{\circledR}$ Terminator $\mathrm{v}$ 3.1 Cycle Sequencing Kit (ThermoFisher Scientifics, Waltham, Massachusetts, USA) together with the BigDye XTerminator ${ }^{\circledR}$ Purification Kit (ThermoFisher Scientifics, Waltham, Massachusetts, USA). The products were sequenced using an ABI $3730 \mathrm{XL}$ automatic sequencer (ThermoFisher Scientifics, Waltham, Massachusetts, USA). Sequences were analyzed with Geneious ${ }^{\mathrm{TM}}$ software v 8.1.9 (Biomatters Limited, Auckland, NZ) to identify single nucleotide polymorphisms (SNPs).

\section{3. rnl Real-Time PCR (Pan-Mucorales Marker)}

For rnl qPCR-high resolution melt (HRM) assay design, $82 \mathrm{rnl}$ sequences representing R. arrhizus, R. microsporus, M. circinelloides, and Lichtheimia spp. complex (L. corymbifera and L. ramosa) were aligned with the $R$. arrhizus reference sequence (GenBank AY863212.1). Primers (2 rnl_127 fw: 5'-GGTGTAGAATACAAGGGAGTCGA-3' and 2 rnl_250 rv: 5'-GGAGAAATCCGCCCCAGATAA-3') generated an amplicon of $124 \mathrm{bp}$. These primers were tested in silico for cross-reactivity with human and not-targeted fungal DNA. The qPCR reaction contained $10 \mu \mathrm{L}$ of SsoFast ${ }^{\mathrm{TM}}$ EvaGreen ${ }^{\circledR}$ Supermix (Bio-Rad Laboratories Incorporated, Hercules, California, USA), $1 \mu \mathrm{L}$ of $10 \mu \mathrm{M}$ of each primer, $6 \mu \mathrm{L}$ of ultrapure water, and $2 \mu \mathrm{L}$ of DNA eluate. All samples were run in duplicate. As positive controls, a set of $n=4$ previously identified representative Mucorales samples (R. arrhizus, R. microsporus, $M$. circinelloides, and Lichtheimia species complexes; AS119, F50, AS84, and FF18, respectively, Table S2) were used as templates, with sterile water (B. Braun, Melsungen, Germany) serving as no template control (NTC). The qPCR reactions were conducted using a CFX96 ${ }^{\mathrm{TM}}$ real-time PCR detection system (Bio-Rad Laboratories Incorporated, Hercules, California, USA) under the following conditions: $98.0^{\circ} \mathrm{C} / 2 \mathrm{~min}$, followed by 40 cycles of $98.0^{\circ} \mathrm{C} / 5 \mathrm{~s}$ and $61.8^{\circ} \mathrm{C} / 10 \mathrm{~s}$.

\section{4. rnl Real-Time PCR-HRM (Species-ID)}

The species identification PCR reaction contained $10 \mu \mathrm{L}$ of SsoFast ${ }^{\mathrm{TM}}$ EvaGreen ${ }^{\circledR}$ Supermix (Bio-Rad Laboratories Incorporated, Hercules, California, USA), $1 \mu \mathrm{L}$ of $10 \mu \mathrm{M}$ of each primer (see rnl 
real-time PCR), $6 \mu \mathrm{L}$ of ultrapure water, and $2 \mu \mathrm{L}$ of each DNA sample ( $20.0 \mathrm{ng} /$ reaction). All samples were run in duplicate with three biological replicates and with positive controls for each species or species complex (R. arrhizus, R. microsporus, M. circinelloides, and Lichtheimia species complexes; AS119, F50, AS84 and FF18, respectively, Table S2). Sterile water (B. Braun, Germany) was used as NTC. The qPCR reactions used a CFX96 ${ }^{\mathrm{TM}}$ real-time PCR detection system (Bio-Rad Laboratories Incorporated, Hercules, California, USA) under the following conditions: $98.0^{\circ} \mathrm{C} / 2 \mathrm{~min}$, followed by 40 cycles of $98.0^{\circ} \mathrm{C} / 5 \mathrm{~s}$ and $61.8^{\circ} \mathrm{C} / 10 \mathrm{~s}$. After denaturation at $98.0^{\circ} \mathrm{C} / 3 \mathrm{~s}$ and cooling at $70.0^{\circ} \mathrm{C} / 30 \mathrm{~s}$, a melt curve was generated from $72.0^{\circ} \mathrm{C}$ to $81.0^{\circ} \mathrm{C}$ with $0.1{ }^{\circ} \mathrm{C}$ increments $/ 5 \mathrm{~s}$ dwell time. Melt curves were processed and analyzed using Precision Melt Analysis ${ }^{\mathrm{TM}}$ software (Bio-Rad Laboratories Incorporated, Hercules, California, USA) to determine average melting temperatures (Tm) and to assign samples to predefined species-specific or species-complex-specific melt profiles.

\subsection{DNA Extraction and $r n l /$ tef $q P C R$ (Quantitative PCR)}

Dissected brains, lungs, livers, and kidneys from black six mice (C57 BL/6 J) were homogenized following an established in-house protocol (refer to submitted paper by Speth et al., PloS Pathogens). All animal experiments were approved by the National Committee for Animal Care of the Austrian Federal Ministry of Science, Research, and Economy (BMWFW) (approval number BMWFW-66.011/0110-WF/V3 b/2016). Organs in Whirl-Paks ${ }^{\circledR}$ (VWR International BVBA, Belgium) frozen in liquid nitrogen were mechanically crushed and then homogenized in cooled $2 \mathrm{~mL}$ Safe Lock Eppendorf ${ }^{\circledR}$ tubes (Eppendorf AG, Hamburg, Germany) using $0.5 \mathrm{~mm}$ steel grinding balls at $30 \mathrm{~Hz}$ for $30 \mathrm{~s}$ in a Mixermill 400 (Retsch, Haan, Germany). Five-point standard curves were prepared as follows: $20 \mathrm{mg}$ of tissue from uninfected mice was spiked either with $20 \mu \mathrm{L} 0.9 \% \mathrm{NaCl}$ as a negative control or with $10^{4}-10^{8}$ Lichtheimia corymbifera (CBS 109940) or R. arrhizus (CBS 126971) cells. DNA was extracted from tissue samples using the DNeasy ${ }^{\circledR}$ Blood and Tissue Kit (Qiagen, Germany). The final elution volume of $200 \mu \mathrm{L}$ contained a total of 15-30 ng of DNA. Two $\mu \mathrm{L}$ samples of the DNA eluate were used in the PCR reaction described above. The standard curve was established with 3 biological replicates and 3 technical replicates for each tissue type and fungus. The qPCR used the rnl real-time protocol above and $\mathrm{R}^{2}$ cut-off values were calculated. The fungal loads of samples were calculated using Bio-Rad CFX Manager 3.1 software with the 5-point standard curve as reference. Consistent results were obtained by analyzing 3 biological replicates for each sample.

\section{6. rnl-tef qPCR (Growth Stage Determination)}

One strain each of L. corymbifera (AS41), R. arrhizus (KOG-D3), M. circinelloides (SPL-CR1), and R. microsporus (AS109) was tested. Samples of $1 \times 10^{6}$ conidia/mL were incubated in $50 \mathrm{~mL}$ liquid SUP at $30{ }^{\circ} \mathrm{C}$ to generate germlings and early hyphae. In pilot experiments, time points for germlings and young hyphae were established based on strain growth kinetics (BioStation IM-Q, Nikon, Vienna, Austria). Fungal development was monitored microscopically (Stemi 2000-C, Carl Zeiss Microscopy, Germany) to verify the harvest time points for germlings and early mycelia. Each experiment used 3 biological replicates and 2 technical replicates. DNA from $1 \times 10^{6}$ conidia, $1 \times 10^{6}$ germlings, or $0.2 \mathrm{~g}$ mycelium was extracted as described by Möller et al. (1992) and spiked with background DNA extracted from human blood samples using the DNeasy ${ }^{\circledR}$ Blood and Tissue Kit (QIAGEN GmbH, Düsseldorf, Germany), as described below for clinical sample mimics. Performance was evaluated for both active stages (germlings, hyphae) and a resting stage (conidia). Rnl real-time PCR was conducted using the following conditions: initial denaturation $95.0^{\circ} \mathrm{C} / 3 \mathrm{~min}$, followed by 45 cycles of $95.0^{\circ} \mathrm{C} / 15 \mathrm{~s}$, $58^{\circ} \mathrm{C} / 30 \mathrm{~s}$, and an extension step at $70.0^{\circ} \mathrm{C} / 3 \mathrm{~min}$. All samples were tested in technical duplicates.

Tef (transcription elongation factor 1-nucleic marker) served as a housekeeping gene for the real-time PCR. Primers for amplification of the 169-bp-long amplicon were designed using Geneious ${ }^{\mathrm{TM}}$ software v. 8.1.9 (Biomatters Limited, Auckland, NZ) and tested in silico for specificity. TEF_468 fw: 5'-GGAGTTCGARACCCCCAAG-3' and TEF_640 rv: 5'-CGGGTTTGACCRTCCTTGGA-3' were applied in a separate qPCR for the samples under the same conditions as for the rnl marker, but with the 
annealing temperature changed to $61.0^{\circ} \mathrm{C}$ [22]. The rnl and tef qPCR runs for the biological triplicates of spores, germlings, and hyphae were conducted in technical duplicates, as were the positive controls (for AS119, F50, AS84, and FF18) and negative controls using pure human background DNA. The fold change between $\mathrm{rnl}$ and tef cycle thresholds was calculated using the formula $2 \Delta \mathrm{C}_{\mathrm{t}}$. Mean values and ranges of $2 \Delta C_{t}$ were calculated for each growth stage. The $2 \Delta C_{t}$ values were used to obtain correlation with the fungal growth stage.

\section{7. rnl Real-Time PCR-HRM Evaluation of Pure Cultures}

The specificity of the rnl real-time PCR-HRM assay was tested blind in comparison to ITS direct sequencing analysis for the 109 strains in our collection (Table S3). All samples were normalized to a concentration of $20 \mathrm{ng}$ DNA/reaction, and positive controls were included for each species or species complex level. The confidence intervals for auto-called clustering were determined using Bio-Rad Precision Melt Analysis ${ }^{\mathrm{TM}}$ software v 1.2 (Bio-Rad Laboratories Incorporated, Hercules, California, USA). Marker species specificity was tested in vitro with DNA extracts from other commonly occurring Mucorales species, namely M. racemosus strain (AS 42), Phycomyces blakesleeanus (CBS 284.35), Cunninghamella bertholletiae (CBS 187.84), Syncephalastrum racemosum (AS 29), and Rhizomucor pusillus (AS 45). Cross-reactivity with other non-Mucorales fungi was tested using DNA extracts from Candida albicans (472 ca), C. tropicalis (424 i), C. glabrata (218 i), C. krusei (124 i), Aspergillus fumigatus (AF293), and A. terreus (118). The limit of detection (LoD) was determined for L. corymbifera (AS10), L. ramosa (33.12), R. arrhizus (LLU-MA1), R. microsporus (75-10), R. microsporus (75-10), and M. circinelloides (60-10), as these are the species most commonly found in Europe [23]. Ten-fold serial dilutions (range: $5.0 \mathrm{ng} / \mu \mathrm{L}-50.0 \mathrm{fg} / \mu \mathrm{L}$ ) of DNA samples were prepared in Endosafe ${ }^{\circledR}$ LAL water (Charles River Laboratories, Inc., USA).

2.8. rnl Real-Time PCR-HRM Evaluation of Assay Performance in Samples Simulating the Human DNA Background of Clinical Specimens

The qPCR LoD of the ID tool was tested using clinical sample mimics based on DNA samples from $200 \mu \mathrm{L}$ freshly drawn EDTA-treated human whole blood, extracted using the peqGOLD Blood DNA Mini Kit (Peqlab Biotechnologies GmbH, Germany), spiked with respective DNA samples of the five species under investigation; namely, L. corymbifera (AS41 A; AS41 B; AS10), L. ramosa (AS75 A; AS75 B; 02-10), M. circinelloides (SPL- CR1; MAL-D3; AS107), R. arrhizus (BOL-CR4; KOG-D3; CM5368), and R. microsporus (75-10; 41-10; 14-11). Ten-fold dilutions series was made with fungal DNA content of $0.001 \%-100 \%$ of total DNA (10 ng) and $0 \%-99.999 \%$ human DNA, respectively. The 100\% human background DNA served as the negative control. To test for potential application in routine diagnostics, the extraction method used instead was the MolYsis ${ }^{\mathrm{TM}}$ Basic5 kit (Molzym GmbH and Co. KG, Bremen, Germany) and the rnl real-time PCR-HRM protocol was modified to a seminested real-time PCR-HRM (see below).

\section{9. rnl Real-Time PCR-HRM Evaluation of Assay Performance in Clinical Sample Mimics}

For clinical sample mimics, aliquots of $200 \mu \mathrm{L}$ EDTA whole blood collected from healthy volunteer donors were inoculated with a ten-fold dilution series of $1 \times 10^{7}-1 \times 10^{2}$ R. arrhizus (KOG-D3) conidia/sample. DNA extraction was performed for all samples, including non-spiked human blood as negative controls. The MolYsis ${ }^{\mathrm{TM}}$ Basic5 kit was used to recover the microbial lysate depleted of human DNA, followed by the DNeasy ${ }^{\circledR}$ Blood and Tissue Kit (QIAGEN GmbH)) according to the manufacturer's instructions.

\subsection{Seminested rnl Real-Time PCR-HRM for Species ID in Clinical Sample Mimics}

DNA extracts were tested in the seminested real-time PCR-HRMA (high resolution melt assay), with the first PCR reaction using a master mix composition and parameters as described for rnl real-time PCR-HRM. The amplicons recovered were diluted 1:300 with sterile water (B. Braun, Germany) and amplified using the same master mix composition in a real-time PCR run according to the following 
protocol: initial denaturation at $98.0^{\circ} \mathrm{C} / 1 \mathrm{~min}$, followed by 20 cycles of $98.0^{\circ} \mathrm{C} / 5 \mathrm{~s}$ and $61.8^{\circ} \mathrm{C} / 30 \mathrm{~s}$; denaturation at $98.0^{\circ} \mathrm{C} / 30 \mathrm{~s}$ and cooling at $70.0^{\circ} \mathrm{C} / 30 \mathrm{~s}$; and generation of melt curve from $72.0^{\circ} \mathrm{C}$ to $81.0^{\circ} \mathrm{C}$, with $0.1{ }^{\circ} \mathrm{C}$ increments $/ 5 \mathrm{~s}$ dwell time. Subsequent analyses were performed as described for rnl real-time PCR-HRM. Species ID control DNAs for the four Mucorales species were extracted using the same procedure and added to each run. All experiments used biological duplicates and technical duplicates.

\subsection{Paraffin-Embedded Tissue (FFPE) of Patients with Proven Fungal Infection and Suspected Mucormycosis}

Samples of biopsies and autopsies were provided by the biobank of the Department of Pathology at the Innsbruck Medical University. The specimens were procured with the approval of the ethics committee (EK 122/04) from patients who gave informed consent. Specimens had been fixed in formalin and embedded in paraffin. Fixed blocks were cut into 3.0- $\mu \mathrm{m}$-thick tissue sections and histologically validated by staining with Grocott and hematoxylin-eosin (HE). Slides were digitized using a Panoramic SCAN digital slide scanner (3 DHISTECH, Budapest, Hungary) with a Plan-Apochromatic objective (magnification: 20×, numerical aperture: 0.8 ). The histological evaluation and the scoring of the fungal infection were done using Panoramic Viewer software (3 DHISTECH, Budapest, Hungary). All tissues were reviewed and screened for mucormycosis. Grocott and hematoxylin-eosin (HE) staining detected hyphae typical of mucormycetes. These hyphae were non-septate or sparsely septate and showed an irregular, ribbon-like appearance. The angle of branching was variable and included wide-angle $\left(90^{\circ}\right)$ bifurcations. The following inclusion criteria for the study were used: (1) diagnosis of invasive mycoses based on histological and clinical findings, (2) diagnosis of mucormycosis based on histological features, and (3) confirmation of the causative agent of mucormycosis by real-time polymerase chain reaction (PCR) or positive culture.

DNA from $3 \times 10 \mu \mathrm{m}$ formalin-fixed, paraffin-embedded (FFPE) tissue sections per sample was extracted using the BioRobot EZ1 (Qiagen) and the EZ1 DNA Tissue Kit (Qiagen), according to manufacturer's instructions (protocol: Purification of DNA from Paraffin-Embedded Tissue). The elution volume was adjusted to $50 \mu \mathrm{L}$. PCR positive samples were purified using the QIAquick PCR purification kit (Qiagen), according to the manufacturer's instructions. The elution volume was adjusted to $30 \mu \mathrm{L}$ using ultrapure water. Eluates were diluted 1:100 in Endosafe ${ }^{\circledR}$ LAL water (Charles River Laboratories, Inc., USA). Twelve $\mu \mathrm{L}$ of the master mix, consisting of $10 \mu \mathrm{L}$ SsoFast ${ }^{\mathrm{TM}}$ EvaGreen $^{\circledR}$ Supermix (Bio-Rad Laboratories Incorporated, Hercules, California, US) and $1 \mu \mathrm{L}$ of $500 \mathrm{nM}$ of each rnl primer (rnl real-time PCR), was added to $8 \mu \mathrm{L}$ of the DNA eluates. Rnl real-time PCR was run in duplicate.

\section{Results}

\section{1. rnl Marker}

The mtDNAs of the targeted mucormycetes species (Rhizopus arrhizus, R. microsporus, M. circinelloides, and Lichtheimia species complexes) are between 54,178 bp for R. arrhizus [24] and $31,830 \mathrm{bp}$ for L. ramosa [25], including the 2878-bp-long rnl gene that encodes the large subunit ribosomal RNA. The gene was selected for Mucorales species identification because of its potential discriminatory power due to 15 single nucleotide polymorphisms (SNPs) found within a specific $279 \mathrm{bp}$ fragment (Figure 1 and Table S3) used as the molecular marker. 


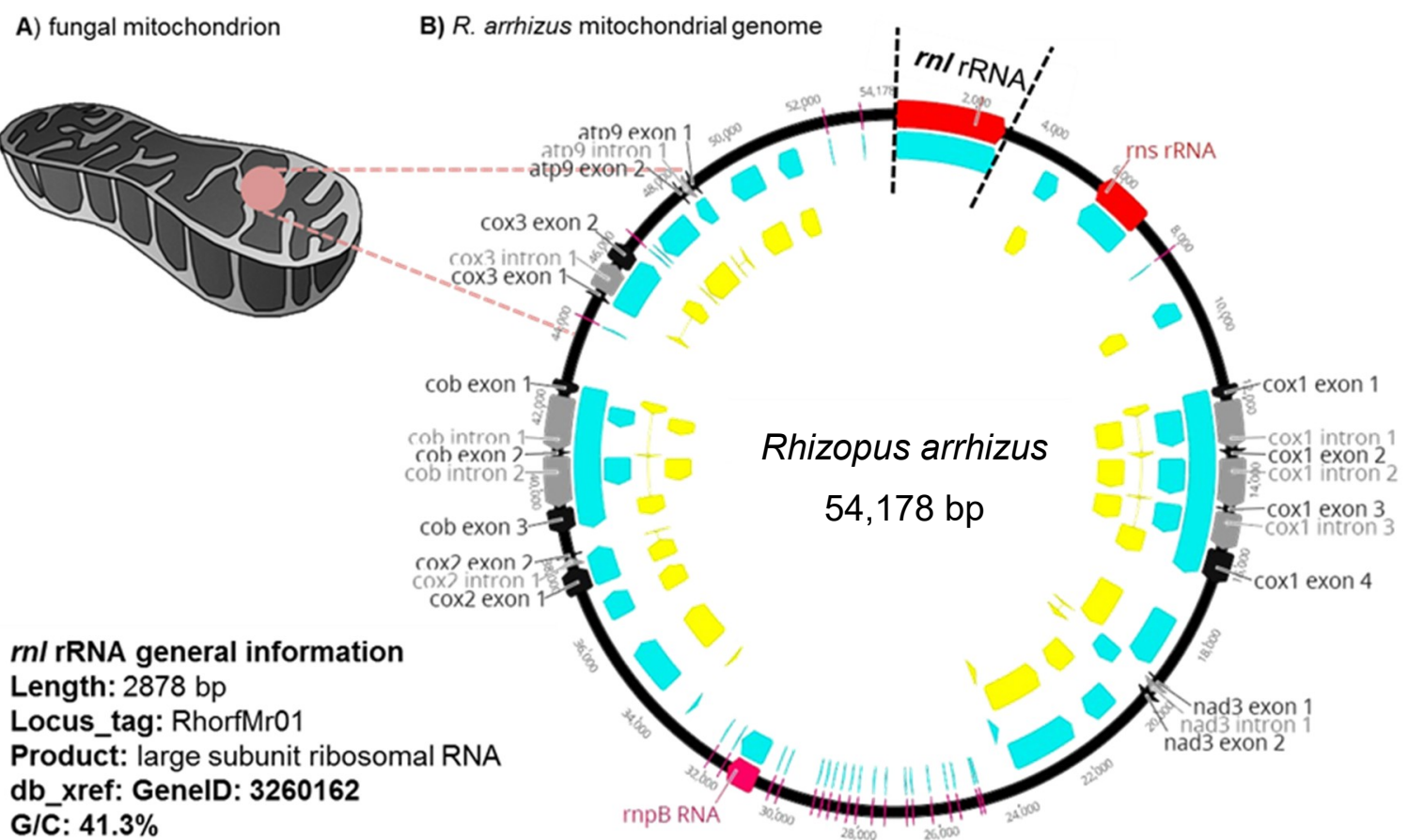

Figure 1. Location of the rnl gene (a large subunit of the ribosomal RNA) in the mitochondrial genome of R. arrhizus. (A) shows a fungal mitochondrion. (B) provides an overview on the mitochondrial genome.

\subsection{Marker Performance in Pure Cultures}

The 279 bp partial fragment of the rnl gene was tested as a pan-Mucorales marker and species ID marker for the most frequently occurring European mucormycetes, namely R. arrhizus, R. microsporus, $M$. circinelloides, L. corymbifera, and L. ramosa. The temperature of $61.8^{\circ} \mathrm{C}$ was optimal for annealing, with an amplification efficacy of $100 \%$ for all species tested (Table S4). The table shows that the sibling species L. corymbifera and L. ramosa had identical SNP profiles. They were, therefore, referred to as the Lichtheimia spp. complex (Figure 2).

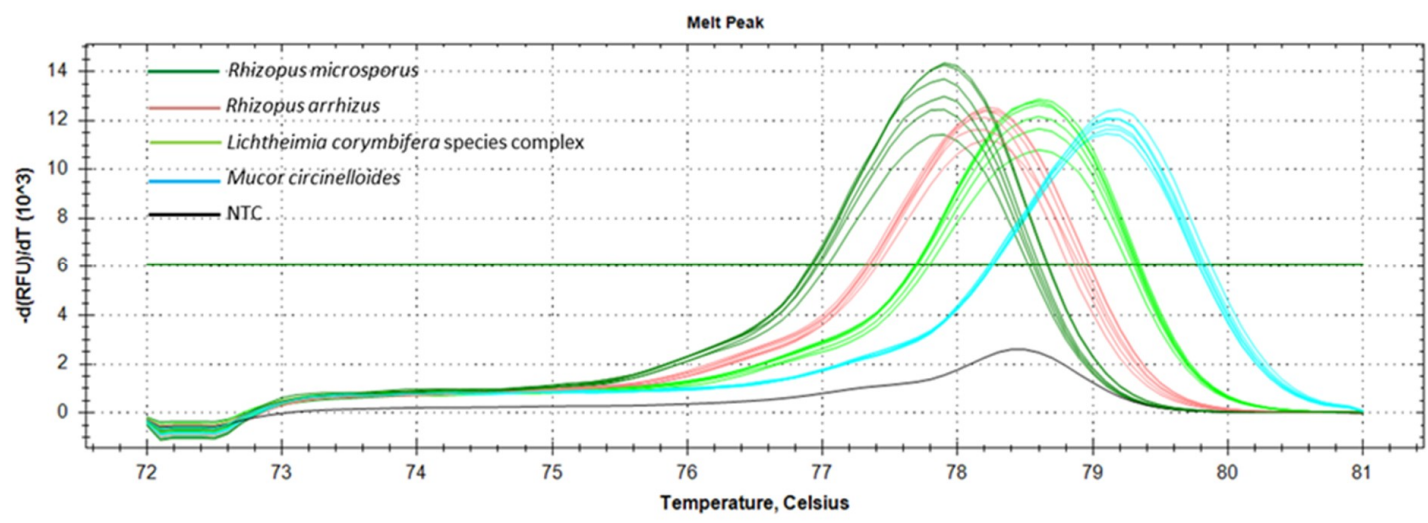

Figure 2. Overview of the melt peaks obtained by rnl real-time PCR-HRM for the targeted Mucorales species and species complexes (Rhizopus arrhizus, R. microsporus, Mucor circinelloides, and Lichtheimia species complexes). Note: NTC $=$ no template control.

To optimize the ID tool, a total of 46 isolates (R. arrhizus $(n=10), R$. microsporus $(n=10)$, and $M$. circinelloides $(n=10)$; L. corymbifera species complex $(n=16))$ were tested. The values obtained for the average melt temperature $(\mathrm{Tm}) \pm \mathrm{SD}$ were evaluated in ten experiments (Figure 3 ). The lowest average Tm was observed for $R$. microsporus $\left(77.78 \pm 0.19^{\circ} \mathrm{C}\right)$, followed by $R$. arrhizus $\left(78.18 \pm 0.11^{\circ} \mathrm{C}\right)$, 
the Lichtheimia spp. complex $\left(78.55 \pm 0.12{ }^{\circ} \mathrm{C}\right)$, and M. circinelloides $\left(79.11 \pm 0.11^{\circ} \mathrm{C}\right)$ (Figure 3C). Both the normalized melt curves (Figure 3A) and difference curves (Figure 3B) distinguished the four taxonomic entities correctly at the species or species complex level, respectively. Blind-tested, unknown samples (two per species) were clustered correctly with the melt profile of their respective positive controls, enabling identification. To comprehensively assess the accuracy of identification using the rnl real-time PCR-HRM, a comparative analysis was conducted with ITS sequencing using a total of 109 ( $L$. corymbifera $(n=31)$, L. ramosa $(n=13)$, R. arrhizus $(n=23)$, R. microsporus $(n=25)$, and M. circinelloides $(n=17))$ strains (Table S4). Species-dependent Tm and confidence ranges for reliable assignments were determined (Figure 3C). The average Tm for each species was distinct (Table S4). The lowest values were found for $R$. microsporus $(77.79 \pm 0.09)$, followed by $R$. arrhizus $(78.10 \pm 0.11)$, Lichtheimia spp. complex (L. corymbifera $78.5 \pm 0.07$ and L. ramosa $78.55 \pm 0.09$ ), and M. circinelloides $(79.09 \pm 0.08)$. Confidence values reaching 100\% were achieved for all species (L. corymbifera $(96.90 \%-100 \%)$, L. ramosa (99.10\%-100\%), R. microsporus $(98.10 \%-100 \%)$, M. circinelloides $(97.60 \%-100 \%))$, except R. arrhizus, whose highest value was $99.90 \%(97.10 \%-99.90 \%)$ (Table S4).
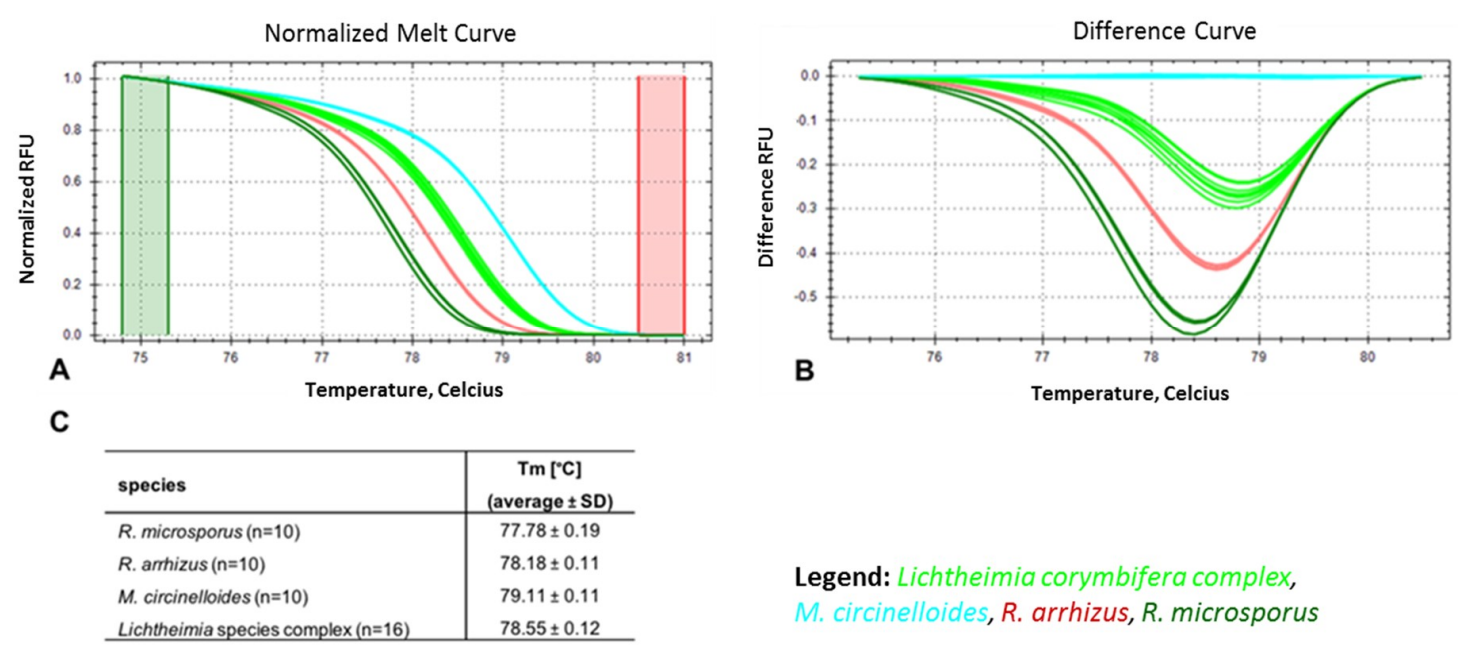

Figure 3. Melt curves: (A) high resolution melt curve, (B) melt difference curve (Tm) with respective standard deviation (SD), and (C) melt temperatures obtained for DNA eluates of $R$. microsporus, $R$. arrhizus, M. circinelloides, and Lichtheimia spp. pure cultures using rnl real time PCR-HRM.

Analysis of the rnl real-time PCR-HRM confirmed pan-Mucorales species specificity. Preliminary in silico screens identified overlaps with 11 other mucoralean sequences deposited in the NCBI database, confirming rnl conservation within the Mucorales order. In vitro testing found that a wide variety of mucormycetes could be detected using rnl real-time PCR-HRM. Among the species tested were: $C$. bertholletiae, M. racemosus, P. blakesleeanus, R. pusillus, and S. racemosum. All species gave distinctly different melt peaks and melt profiles. Unspecific clustering among the four target species was not observed (Figure S1A-C).

Cross-reactivity with non-mucoralean fungal species and the human and murine genomes was excluded in silico. Cross-reactivity in routine diagnostics with commonly encountered ascomycetes, namely Candida and Aspergillus species, was excluded using additional in vitro tests. Cross-reactivity with human and murine DNA was also excluded by testing those DNAs in vitro. Rnl real-time PCR-HRM did not amplify C. albicans, C. glabrata, C. krusei, C. tropicalis, A. fumigatus, and A. terreus samples (i.e., no cross-reactivity of the rnl marker was observed) (Figure S2). Thus, the rnl marker is a highly specific pan-Mucorales marker. The limit of detection (LoD) for rnl real-time PCR was found to be $50.0 \mathrm{fg} / \mu \mathrm{L}$ per reaction, equating to one genome copy $\left(C_{t}\right.$ value of $33.17 \pm 1.64$ for one $R$. arrhizus genome, $37.54 \pm 0.32$ for one $R$. microsporus genome, $34.65 \pm 0.68$ for one $M$. circinelloides genome, and $36.91 \pm 1.16$ for one Lichtheimia spp. genome) (Figure $4 \mathrm{~A}, \mathrm{~B}$ ). For species identification via rnl real-time PCR-HRM analysis, 400-500 fg DNA (equal to 10 genomes; genome size of R. arrhizus is 
45.26 Mbp, R. microsporus is $25.97 \mathrm{Mbp}, M$. circinelloides is $36.6 \mathrm{Mbp}$, and Lichtheimia spp. complex are $33.6 \mathrm{Mbp}$ ) was needed for identification with a confidence of $90.50 \%-100 \%$. $C_{t}$ values for 10 genome copies were 32.49 for $R$. arrhizus, 35.25 for $R$. microsporus, 28.97 for M. circinelloides, and 32.70 for Lichtheimia spp. complex (Figure 4C,D).
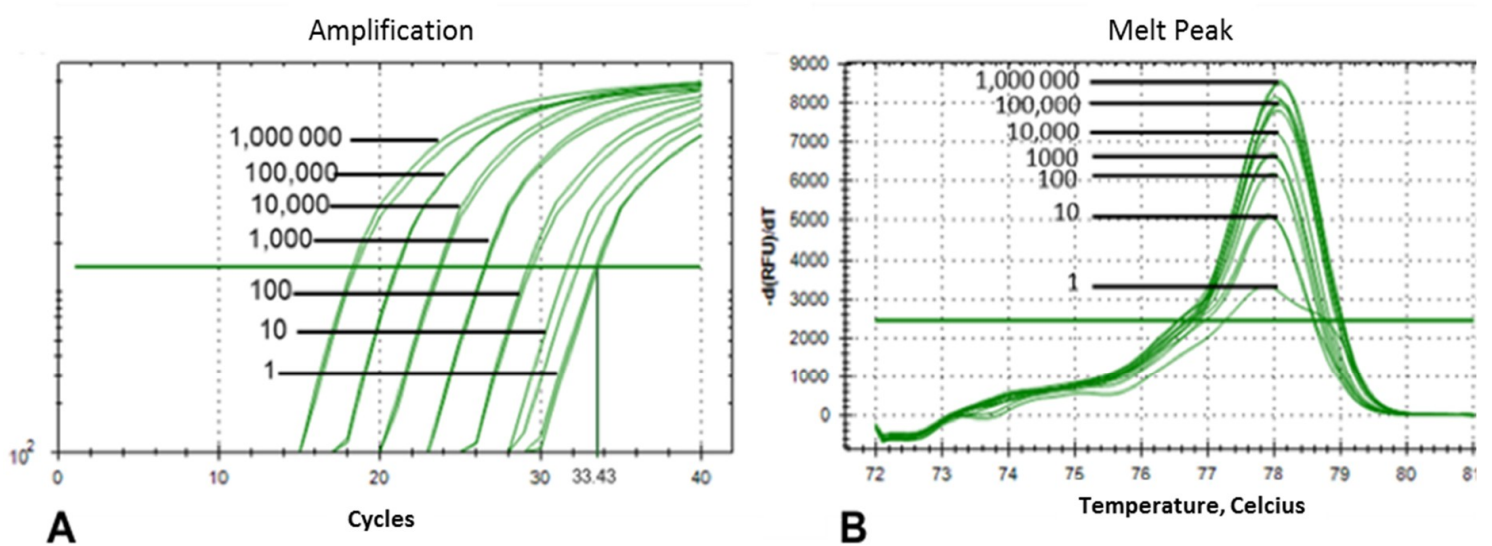

C

D
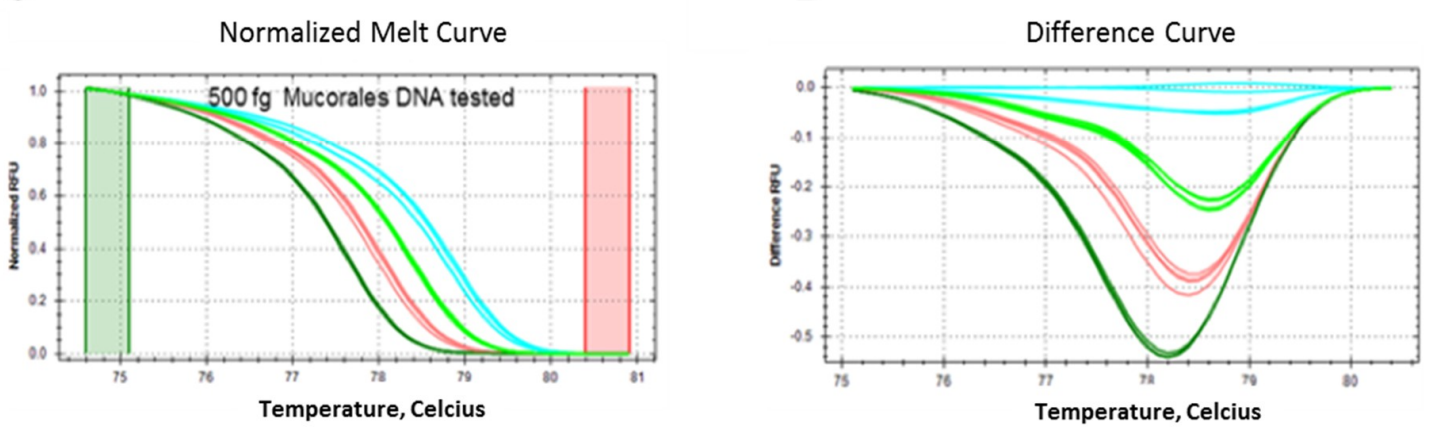

Legend: Lichtheimia species complex, M. ciricnelloides, R. arrhizus, R. microsporus

Figure 4. Limit of detection of the rnl real-time PCR-HRM in pure cultures. (A) Amplification of the rnl fragment for each genome copy number. (B) Melt peaks for each genome copy number. (C) HRMA melt curves for $500 \mathrm{fg}$ of tested mucoralean DNA from all species under investigation. (D) Difference curve for species identification.

\subsection{Rnl Marker Evaluation with Human DNA Background}

Clinical specimen mimics consisted of human background DNA extracted from EDTA whole blood spiked with fungal DNA. The LoD for rnl real-time PCR detection was found to be $100.0 \mathrm{fg}$ mucoralean DNA/initial sample for all species of interest, with cycle thresholds displaying average values of $36.35 \pm 0.60$ for L. corymbifera, $36.69 \pm 0.46$ for L. ramosa, $34.76 \pm 0.92$ for $R$. arrhizus, $35.24 \pm 0.43$ for $R$. microsporus, and $33.47 \pm 0.63$ for $M$. circinelloides. The ranges of linearity differed between the species. The broadest range of linearity was seen with $M$. circinelloides ( $0.1 \mathrm{pg}-1.0 \mathrm{ng}$ fungal DNA/ $\mu \mathrm{L}$ total DNA) and L. corymbifera (1.0 pg-10 ng fungal DNA/ $\mu \mathrm{L}$ total DNA), followed by R. arrhizus (1.0 pg-1.0 ng fungal DNA/ $\mu \mathrm{L}$ total DNA), L. ramosa (100.0 pg-1.0 ng fungal DNA/ $\mu \mathrm{L}$ total DNA), and R. microsporus (100.0 pg-1.0 ng fungal DNA/ $\mu \mathrm{L}$ total DNA). The coefficients of determination were all greater than 0.99 (Figure S4).

\subsection{Seminested Real-Time PCR-HRM for Conidia-Spiked, EDTA-Treated Human Blood Samples}

When the rnl real-time PCR-HRM assay was tested using conidia-spiked human blood samples, positive amplification to a concentration of 1 conidia/200 $\mu \mathrm{L}$ blood sample (corresponds to 0.1 conidia/PCR reaction; $2 \mu \mathrm{L}$ of DNA eluate were used from the total $20 \mu \mathrm{L}$ DNA eluate) was 
achieved, with an average $C_{t}$ value of 36.98. Several melt curves of the serial dilution were linear at this concentration (Figure S4). Identification based on the HRM profile was possible down to $10^{4}$ R. arrhizus-conidia-spiked in $200 \mu \mathrm{L}$ blood, equating $10^{3}$ R. arrhizus conidia/PCR reaction (Figure 5). Lower concentrations of fungal DNA could not be assigned to the correct melt profile.
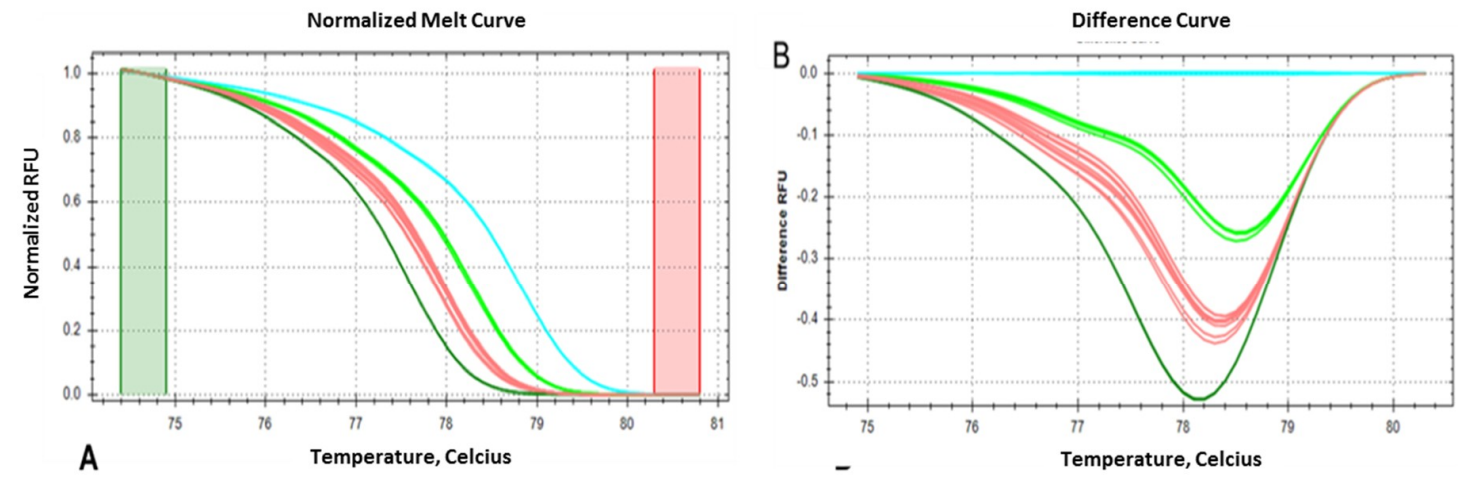

Legend: Lichtheimia species complex, M. cinconelloides, R. arhizus, R. microsporus

Figure 5. Sensitivity of the rnl real-time PCR-HRM assay for human EDTA-whole blood samples spiked with R. arrhizus conidia in serial dilutions. (A) Normalized melt curve and (B) difference curves for individual species.

\section{5. rnl Real-Time qPCR for the Detection of Fungal Burden in Murine Organs}

A murine organ model was established to provide standardized samples of kidney, spleen, liver, lung, and brain tissue for determination of fungal burden/20 $\mathrm{mg}$ tissue using $\mathrm{rnl}$ qPCR. Data are given in Figure 6. We obtained linear trend lines for the ten-fold dilution series of $10^{8}$ to $10^{4}$ spores per sample. L. corymbifera-spiked samples led to coefficients of determination $R^{2}>0.95$ for brain and lung, $R^{2}>$ 0.90 for kidney, and $R^{2}>0.85$ for liver and spleen; whereas $R$. arrhizus spiked samples gave $R^{2}>0.95$ for kidney, brain, and lung, and $\mathrm{R}^{2}>0.90$ for liver and spleen. The consistent results delivered by $\mathrm{rnl}$ qPCR show that rnl is a robust marker for fungal burden evaluation (Table S5). Independent evaluation by other laboratories should now be a priority.
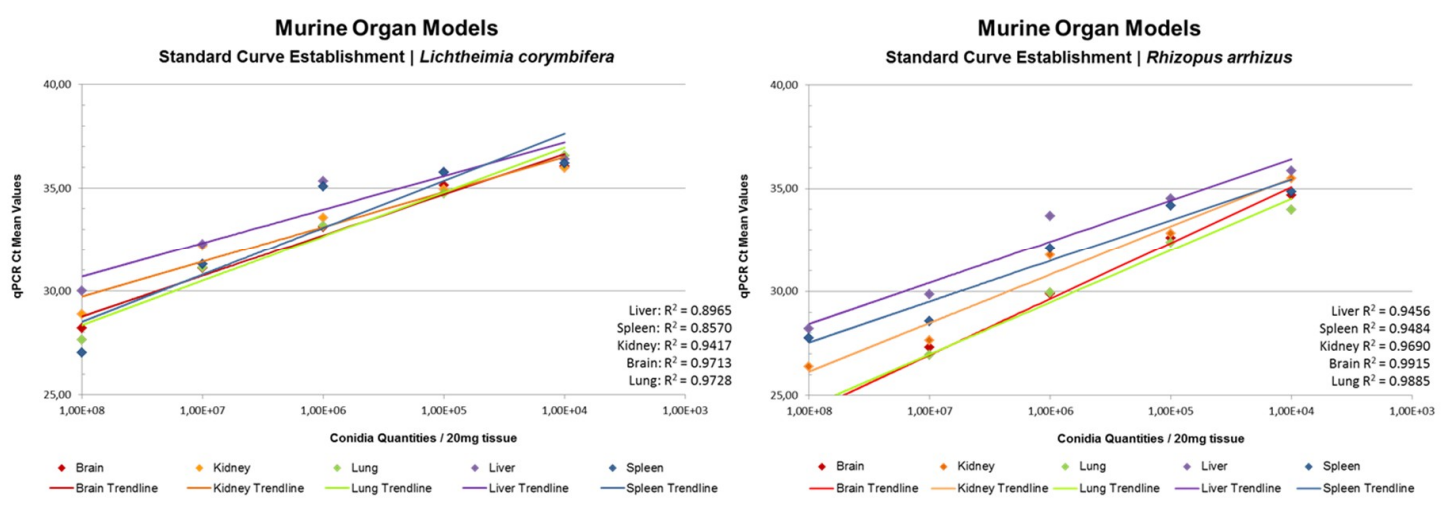

Figure 6. Standard curve obtained for murine organ models of conidia-spiked brain, kidney, lung, liver, and spleen. Values are given per $20 \mathrm{mg}$ tissue. (A) Standard curves for L. corymbifera. (B) Standard curves for R. arrhizus. Standard deviations are given in Table S5.

\subsection{Growth Stage Determination Using rnl/tef $q P C R$}

The ability of the rnl marker to identify resting and active growth stages of Mucorales in clinical sample mimics was investigated. The activity stage was detected using the fold change $\left(2 \Delta C_{t}\right)$ between the rnl mitochondrial marker and the nucleic tef housekeeping gene. Mitochondrial DNA occurs in 
larger amounts in active fungal cells than in resting conidia. The rnl/tef qPCR found that $\mathrm{C}_{\mathrm{t}}$ values obtained by rnl primers were lower than the ones obtained by tef primers. The sensitivity of rnl marker was higher than the tef marker, with an average cycle difference of 2.26 for conidia, 3.32 for germlings, and 3.20 for hyphae. This confirms higher abundance of mtDNA compared to nDNA present in the samples (Figure S5). Fold changes of rnl compared to tef were found to be 4.98 in spores (minimum, 3.99; maximum, 5.52), 10.75 in germlings (minimum, 8.77; maximum, 12.82), and 8.61 in hyphae (minimum, 6.95; maximum, 11.06). These results define a cut-off value of 5.60 that differentiates between the resting (spores) and active growth (germlings, hyphae) stages of mucormycetes (Figure 7).

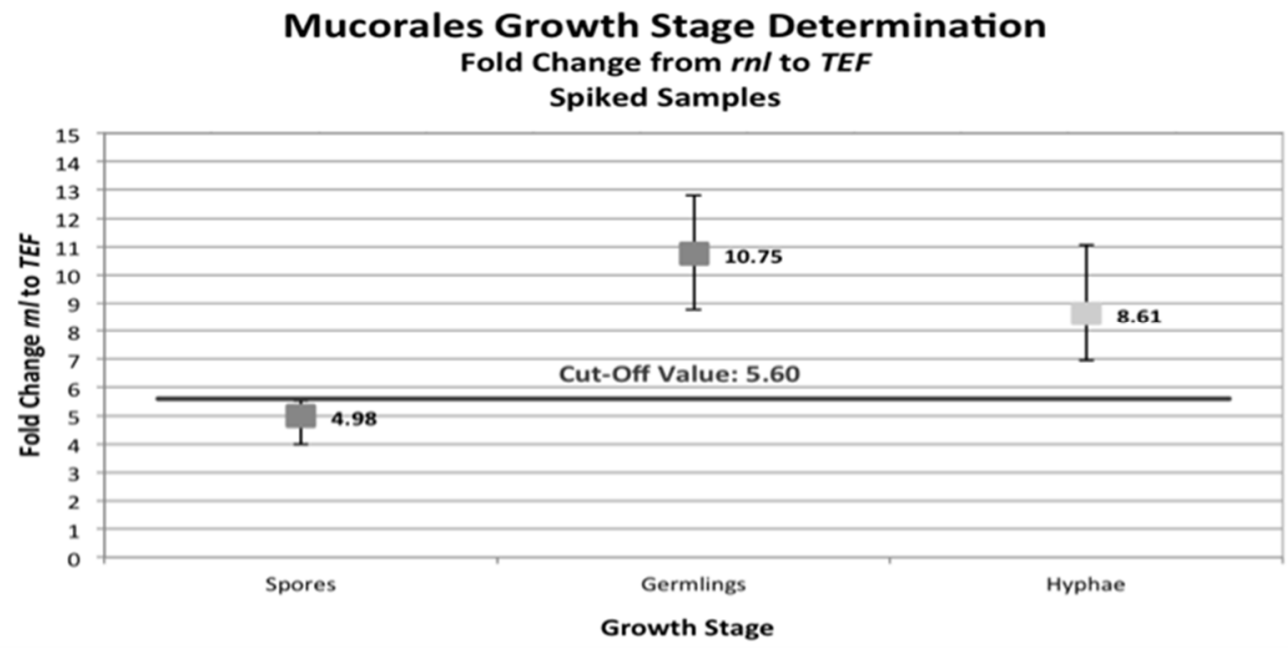

Figure 7. Growth stage determination of the Mucorales species investigated. Minima, medians, and maxima of the fold-change evaluation between the mitochondrial rnl marker and nuclear tef marker are plotted against the corresponding growth stages. The defined cut-off value of 5.60 ascertained via $2 \Delta C_{t}$ differentiates the resting (spores) and active (germlings or hyphae) developmental stages.

\section{7. rnl as a Pan-Mucorales Marker in FFPE Tissue Samples}

The performance of rnl as a pan-Mucorales marker was evaluated for FFPE tissue samples. The rnl real-time PCR assay was carried out on 21 clinical samples previously diagnosed with suspected Mucorales infections via culture and microscopic examination. Of 21 samples, 15 (71.4\%) were pan-Mucorales positive compared to $8(50 \%)$ of 16 samples that tested positive by UMD Universal ${ }^{\circledR}$ (Molzym) pan-fungal PCR (commercial kit used in routine diagnostics). Four samples found positive with rnl real-time PCR were negative with UMD Universal kit (Molzym). These included two autopsy samples with insufficient quality DNA for the UMD Universal kit. One sample not detected by pan-Mucorales PCR was found to be positive by the pan-fungal PCR, and Candida spp. was detected as the causative species. Another sample that was negative with the pan-Mucorales marker was not tested with the UMD Universal kit. Only its histology was indicative of a fungal infection but that might have been caused by an ascomycete or basidiomycete. Detailed results are given in Table 1 . 
Table 1. Results from paraffin-embedded tissue (FFPE) samples from patients with proven fungal infection and suspected mucormycosis.

\begin{tabular}{|c|c|c|c|c|c|c|c|}
\hline \multirow[b]{2}{*}{ Patient ID } & \multirow[b]{2}{*}{ Sample Type } & \multirow[b]{2}{*}{ Tissue Type } & \multicolumn{2}{|l|}{ Histology } & \multicolumn{2}{|c|}{ Routine Diagnostic PCR } & \multirow{2}{*}{$\begin{array}{c}\text { Novel PCR } \\
\text { Pan-Mucorales }\end{array}$} \\
\hline & & & Histology/Pathology Diagnosis & $\begin{array}{c}\text { Microscopy } \\
\text { (Grocott Staining) }\end{array}$ & Pan-Fungal PCR & $\begin{array}{c}\text { Culture or } \\
\text { Pan-Fungal PCR ID }\end{array}$ & \\
\hline $\mathrm{TR}$ & histology & lung & $\begin{array}{l}\text { necrotizing mucormycosis with } \\
\text { tissue invasion } \\
\text { inflammatory reaction with }\end{array}$ & $(+)$; mucormycosis & $(-)$ & no ID & $(-)$ \\
\hline HJ & histology & lung & $\begin{array}{l}\text { macrophages of connective tissue, } \\
\text { with embedded fungal structures, } \\
\text { most probably mucormycetes }\end{array}$ & $(+)$; mucormycosis & $(-)$ & no ID & $(-)$ \\
\hline KA & histology & lymph node, lung & $\begin{array}{c}\text { necrotizing pneumonia caused by } \\
\text { a fungus }\end{array}$ & $\begin{array}{c}(-) \text {; single } \\
\text { unidentifiable } \\
\text { hyphae }\end{array}$ & $(-)$ & no ID & $(-)$ \\
\hline VM & histology & skin ulcer & $\begin{array}{c}\text { abscess building panniculitis due } \\
\text { to sepsis with fungi, suspected } \\
\text { mucormycosis }\end{array}$ & $(+)$; mucormycosis & not performed & not available & $(+)$ \\
\hline PG & histology & lung & $\begin{array}{c}\text { lung tissue with bronchiolitis } \\
\text { obliterans with organizing } \\
\text { pneumonia (BOOP) and fungal } \\
\text { infection (mucormycosis) }\end{array}$ & $\begin{array}{c}(+) \text {; fungal elements } \\
\text { suspected } \\
\text { mucormycosis }\end{array}$ & not performed & $\begin{array}{l}\text { Rhizopus arrhizus } \\
\text { (culture) }\end{array}$ & $(+)$ \\
\hline WC & histology & jaw & $\begin{array}{l}\text { necrotic, inflammatory connective } \\
\text { tissue with evidence of fungi, } \\
\text { correlating to a mucormycosis }\end{array}$ & $(+)$; mucormycosis & $(+)$ & $\begin{array}{l}\text { Candida sp., } \\
\text { Cryptococcus sp. }\end{array}$ & $(+)$ \\
\hline $\mathrm{HI}$ & histology & maxillary sinus & $\begin{array}{c}\text { extensive fungal infection of } \\
\text { sinus maxillaris }\end{array}$ & $\begin{array}{l}\text { Grocott stain not } \\
\text { performed }\end{array}$ & not performed & not available & $(+)$ \\
\hline ML & histology & lung & mucormycosis of lingula & $(+)$; mucormycosis & $(-)$ & mucormycete (culture) & $(+)$ \\
\hline LR & histology & lung & fungal structures & $\begin{array}{l}\text { Grocott stain not } \\
\text { performed }\end{array}$ & not performed & not available & $(-)$ \\
\hline EJ & histology & skin ulcer & $\begin{array}{l}\text { suspected mucormycosis } \\
\text { the material of ulcer and fungal }\end{array}$ & $\begin{array}{l}(+) ; \text { mucormycosis } \\
(+) \text {; no septate }\end{array}$ & $(+)$ & Candida spp. & $(-)$ \\
\hline $\mathrm{NN}$ & histology & stomach & $\begin{array}{l}\text { structures, invasive } \\
\text { mucormycosis }\end{array}$ & $\begin{array}{l}\text { hyphae, } \\
\text { mucormycosis }\end{array}$ & $(+)$ & Rhizomucor pusillus & $(+)$ \\
\hline $\mathrm{BH}$ & histology & the soft tissue of & both samples fat tissue necrosis of & $\begin{array}{l}\text { Grocott stain not } \\
\text { performed }\end{array}$ & $(+)$ & Rhizopus microsporus & $(+)$ \\
\hline $\mathrm{BH}$ & histology & & th & & & & $(+)$ \\
\hline
\end{tabular}


Table 1. Cont

\begin{tabular}{|c|c|c|c|c|c|c|c|}
\hline \multirow[b]{2}{*}{ Patient ID } & \multirow[b]{2}{*}{ Sample Type } & \multirow[b]{2}{*}{ Tissue Type } & \multicolumn{2}{|l|}{ Histology } & \multicolumn{2}{|c|}{ Routine Diagnostic PCR } & \multirow{2}{*}{$\begin{array}{c}\text { Novel PCR } \\
\text { Pan-Mucorales }\end{array}$} \\
\hline & & & Histology/Pathology Diagnosis & $\begin{array}{c}\text { Microscopy } \\
\text { (Grocott Staining) }\end{array}$ & Pan-Fungal PCR & $\begin{array}{c}\text { Culture or } \\
\text { Pan-Fungal PCR ID }\end{array}$ & \\
\hline $\mathrm{PN}$ & autopsy & pleura aspirate & $\begin{array}{l}\text { invasive mucormycosis with } \\
\text { organizing pneumonia; epicardial } \\
\text { myocarditis with fungal elements; } \\
\text { two "Kissing" ulcers in the } \\
\text { stomach with a fungal infection, } \\
\text { suspected mucormycosis }\end{array}$ & $\begin{array}{l}(+) \text {; no septate } \\
\text { hyphae; } \\
\text { mucormycosis }\end{array}$ & $(+)$ & Rhizopus arrhizus & $(+)$ \\
\hline GS & autopsy & lung & $\begin{array}{l}\text { irreversible lung collapse due to } \\
\text { mucormycosis }\end{array}$ & $\begin{array}{l}\text { Grocott stain not } \\
\text { performed }\end{array}$ & $(+)$ & Lichtheimia spp. & $(+)$ \\
\hline WE & autopsy & lung & $\begin{array}{l}\text { invasive fungal infection, } \\
\text { suspected aspergillosis or } \\
\text { mucormycosis }\end{array}$ & $\begin{array}{l}(+) ; \text { no septate } \\
\text { hyphae, } \\
\text { mucormycosis }\end{array}$ & $(+)$ & Rhizomucor pusillus & $(+)$ \\
\hline $\mathrm{TM}$ & autopsy & lung & $\begin{array}{l}\text { fungal pneumonia, suspected } \\
\text { aspergillosis }\end{array}$ & $\begin{array}{l}\text { Grocott stain not } \\
\text { performed }\end{array}$ & $\begin{array}{l}\text { insufficient DNA } \\
\text { quality }\end{array}$ & not available & $(+)$ \\
\hline $\mathrm{BB}$ & autopsy & lung & $\begin{array}{l}\text { invasive sepsis due to generalized } \\
\text { invasive fungal infection }\end{array}$ & $\begin{array}{l}(+) ; \text { no septate } \\
\text { hyphae, } \\
\text { mucormycosis }\end{array}$ & $\begin{array}{l}\text { insufficient DNA } \\
\text { quality }\end{array}$ & $\begin{array}{l}\text { Rhizopus microsporus } \\
\text { (culture) }\end{array}$ & $(-)$ \\
\hline LRo & autopsy & lung & $\begin{array}{l}\text { multiple infected sides, suspected } \\
\text { mucormycosis }\end{array}$ & $\begin{array}{l}(+) ; \text { no septate } \\
\text { hyphae, } \\
\text { mucormycosis }\end{array}$ & $\begin{array}{l}\text { insufficient DNA } \\
\text { quality }\end{array}$ & not available & $(+)$ \\
\hline SI & autopsy & lung & $\begin{array}{l}\text { periphery pulmonary embolism } \\
\text { and pulmonary infraction } \\
\text { including fungal elements, } \\
\text { suspected mucormycosis }\end{array}$ & $\begin{array}{l}(+) ; \text { no septate } \\
\text { hyphae, } \\
\text { mucormycosis }\end{array}$ & $(-)$ & Lichtheimia corymbifera & $(+)$ \\
\hline VL & autopsy & tissue of the cheek & $\begin{array}{c}\text { fungal burden, mucormycosis, } \\
\text { evidence of mixed yeast and } \\
\text { mucormycete infection within } \\
\text { pulmonary tissue }\end{array}$ & $\begin{array}{l}(+) \text {; } \text { no septate } \\
\text { hyphae, } \\
\text { mucormycosis }\end{array}$ & $(+)$ & Lichtheimia corymbifera & $(+)$ \\
\hline
\end{tabular}




\section{Discussion}

Patients suffering from mucormycosis exhibit signs and symptoms similar to patients suffering from other invasive fungal infections, such as aspergillosis [26,27]. The ability to diagnose mucormycosis separately from other fungal infections is essential for therapeutic management and to improve patient outcomes. In contrast to mucormycosis, the primary therapy for aspergillosis and scedosporiosis is voriconazole, a short-tailed azole drug that is ineffective against mucormycetes [28,29]. In contrast, the primary therapy for mucormycosis is amphotericin B [30]. Therefore, diagnostic tools that distinguish mucormycosis from other fungal infections are needed urgently [31].

Current diagnostics for mucormycetes primarily use direct imaging, histopathology, culture, and direct examination [32]. These follow the recommendations of the International Society for Human and Animal Mycology working group, which has also suggested ITS sequencing as the gold standard [33]. Despite the development of several PCR-based assays, these have focused on different genera or species [17] and have almost exclusively involved nuclear ribosomal DNA targets (18 S, $28 \mathrm{~S}$, and internal transcribed spacer (ITS)) [34-40]. However, nuclear ribosomal genes appear to be inadequate targets as pan-Mucorales markers. The ITS region exhibits intraspecific variability within 3.24\% of the Mucoromycotina [41]. Moreover, heterogeneity of ITS 1 and ITS 2 sequences has been detected in R. microsporus [42]. Additionally, the discriminatory power for other fungal pathogens at the order level is too limited. We rationalized that a new approach that discriminates mucormycosis from aspergillosis and candidiasis could enable prompt diagnosis and customized antifungal treatment. So far, only two pan-Mucorales markers that identify clinical specimens have been published. The first is a PCR technique targeting the spore-coating encoding protein $(\mathrm{CotH})$ gene $[12,13]$, and is mainly used for urine samples. The commercial PCR MucorGenius ${ }^{\circledR}$ was launched recently by PathoNostics ${ }^{\circledR}$, but for research purposes only. Unfortunately, the molecular basis of the test is not available (https:/www.pathonostics.com/product/mucorgenius) and the assay is yet to be validated on clinical specimens. Some authors have also suggested a combinational approach, using different biomarkers for early diagnosis of mucormycosis [8].

Pan-Mucorales detection may require alternative gene regions that are conserved within the mucormycetes and distinctly different from ascomycetes and basidiomycetes. This report has investigated rnl (Figure 1) as an example of a mitochondrial marker. We first evaluated its suitability as a marker for: (1) pan-Mucorales identification, (2) species identification (Rhizopus arrhizus, $R$. microsporus, Mucor circinelloides, and Lichtheimia species complex), (3) growth stage determination, and (4) quantification. The mitochondrial gene has the following advantages for the detection and identification of Mucorales: (1) high copy number of mitochondrial genes per fungal cell; (2) enhanced stability due to the mitochondrial double membrane, increasing the chance it can be extracted despite low quality or highly degraded nuclear DNA in samples [43,44]; (3) lower sequence heterogeneity than ITS sequences [42], and as our results show, no intraspecific variability. The rnl gene was found to be a suitable candidate marker gene because a universal primer pair could be designed to select a well-conserved region within the gene, despite the presence of introns in fungal mitochondrial genomes [43]. The primer pair enabled the establishment of all the rnl-based PCR formats reported herein (see Materials and Methods). The primer set provides a common core reaction for PCR formats for in silico and in vitro studies, and analysis of clinical specimen mimics, animal tissues, and FFPE. The primer set was evaluated in silico and in vitro for its cross-reactivity with human and murine DNA. No cross-reactivity was detected, even at very high DNA concentrations (10 ng/PCR reaction).

In a second phase of testing, cross-reactivity with other non-Mucorales fungal pathogens was evaluated in silico because precise and clear discrimination of Mucorales from human pathogenic ascomycetes (e.g., Aspergillus and Candida) and basidiomycetes (e.g., Cryptococcus) is essential for targeted treatment [17]. As Aspergilli and Candida spp. are the most common agents of fungal infections, representative species were also tested also in vitro. Primer dimers were found above $C_{t}>38$ for $C$. glabrata, A. fumigatus (Figure S2), and in the no template control (NTC). A cutoff value for positivity calling of $C_{t} 38$ is recommended for rnl real-time PCR. Hence, cross-reactivity for A. fumigatus and $A$. 
terreus, as well as C. krusei, C. tropicalis, C. glabrata, and C. albicans, could be excluded. The amplification of rnl from other mucormycetes was confirmed in silico and is shown in Figure S1. Key measures, such as LoD of the assay for pan-Mucorales positivity and species identification, were one genome copy and ten genome copies, respectively (Figure 4).

The potential of rnl as a marker suitable for species identification was confirmed for four of the most common causes of mucormycosis in Europe (R. arrhizus, R. microsporus, M. circinelloides, and Lichtheimia species complex) (Figure 2). The two sibling species, Lichtheimia corymbifera and L. ramosa, could not be distinguished. This is not a clinical limitation, as there is no evidence of differences in resistance or virulence [45]. The basis for HRM identification is 15 SNPs present in the partial rnl fragment (Table S3). The rnl real-time PCR-HRM delivered the same results as ITS sequencing (Figure 2 and Table S4). Real-time PCR-HRM assays for species identification have previously been established for bacteria [46,47], protozoans [48], and other fungi [38,49-55]. Bialek et al. (2005) [56] published an alternative PCR-HRM approach using $18 \mathrm{~S}$ rDNA primers and an intercalating dye, similar to our study. We identified the most common European mucormycetes in pure cultures and clinical specimens. The identification of pure cultures is, therefore, feasible and should be further developed (Figure 3 and Figure S1). For pure cultures, the method is ideal for rapid in-house testing. It does not require databases or expensive equipment, has high sensitivity due to the real-time format using intercalating dyes, and has low setup costs. For species identification, the LoD for assays was approximately 10 genome copies/mL in spiked whole blood samples (Figure 5). Even though the LoD for species identification was 10-fold higher than for the pan-Mucorales marker only, previous studies suggest the fungal DNA load in serum samples of patients suffering from invasive mucormycosis is approximately 10- to 100-fold higher than in patients suffering from aspergillosis [57]. This should facilitate species identification in patient blood samples. The testing of blood samples from patients with invasive mucormycosis is now needed to assess the performance of the assay in routine diagnostic settings. All published real-time PCR methods that detect the causative agent on a genus level $[39,57,58]$ or species level require subsequent sequencing of the PCR product [59]. Blood-based screening PCRs are especially useful for high-risk patients. The PCR-HRM assay is expected to diagnose the most common causative agents within one working day in pure cultures and blood samples, without the need for DNA sequencing.

The rnl marker was evaluated as a pan-Mucorales marker in FFPE samples (Table 1). Fifteen out of 21 samples $(71.4 \%))$ were positive with the pan-Mucorales marker. However, the previous diagnosis Mucorales-positive infection in two of the negatively tested samples appears questionable. One was found Candida-positive by the pan-fungal PCR (suggesting co-infection or infection by Candida alone). The other sample was described by histology only as an invasive fungal infection, without further evidence of mucormycosis. Exclusion of these two samples makes the sensitivity $78.9 \%$. A limitation of our study was that fresh tissue samples were not available. It is known that, independent of the assay format, analytic sensitivity of fresh tissue is between $97 \%-100 \%$, and for FFPE only is between $56 \%$ and $80 \%$ [5]. Our rnl real-time PCR assay needs to be evaluated using fresh tissue samples to assess its full potential and to determine its specificity and sensitivity. Application of the two different PCRs (UMD universal Molzym and rnl real-time PCR) to the same clinical material showed that the sensitivity of our method at $71.4 \%-78.9 \%$ outperformed the $50 \%$ sensitivity of the commercial assay. The mitochondrial markers may be especially useful for necrotic tissues because of their likely resistance to degradation. In particular, the rnl-based PCR detected rnl in two out of three samples and outperformed the $28 \mathrm{~S}$ rDNA based Molzym assay, which failed to detect its target in the same autopsy samples. Studies on comprehensive sample sets are needed to confirm these preliminary results.

The rnl-qPCR successfully quantified fungal burden in murine organs (brain, lung, liver, and kidney) using species-specific standardization curves generated for Lichtheimia corymbifera and Rhizopus arrhizus (Figure 6). Its high $\mathrm{R}^{2}(85-95 \%)$ makes $\mathrm{rnl}$ a robust marker for the determination of fungal burden. For pulmonary infection models, rnl/tef qPCR can be used to determine both fungal burden and fungal growth stage. This should allow, especially in pulmonary infection models, 
differentiation between resting conidia and active proliferating hyphae. To the authors' knowledge, rnl provides the first growth stage marker for a fungus based on real-time PCR assay. The growth stage determination was possible in both pure cultures and clinical sample mimics (Figure 7). The assay uses the principle that mitochondrial biogenesis differs between the resting and active cell stages and results in a variation in the ratio of mitochondrial DNA molecules and nuclei [60]. Germlings and hyphae require more energy than spores as a resting stage. The greater mitochondrial abundance found in active stages is paralleled by an increased number of rnl genes per cell (Figure 7). This elevation in template levels lowers cycle thresholds for the correspondent samples in qPCR. The chosen internal control gene, tef, is located in the nuclear DNA, and is, therefore, proportional to the presence of nuclei. The changing relationship between nuclei and mitochondria enables discrimination between the different growth stages. Resting stages had a $2 \Delta C_{t}<5.60$ and active stages had a $2 \Delta C_{t}>5.60$. In our experiments, this value discriminates between the growth stages for all mucormycetes tested, namely R. arrhizus, R. microsporus, M. circinelloides, and Lichtheimia species. This cut off value might vary between PCR platforms, experimental conditions, and fungal species tested. As this is the first study to use this approach, we look forward to future comparative data from other laboratories. The ability to discriminate between the various growth stages may be of interest for other human pathogenic fungi; for example, aspergilli in respiratory tract samples such as bronchoalveolar lavages, where discrimination between colonization and infection during aspergillosis remains a significant challenge [61].

\section{Conclusions}

Our data show rnl, a representative gene of mtDNA, is a promising marker that can be used for various research and diagnostic applications. The rnl fragment marker identifies the most common mucormycete species (R. arrhizus, R. microsporus, M. circinelloides, and Lichtheimia spp. complex) in pure cultures. For clinical specimens, the marker's main strength is its ability to serve as a pan-Mucorales marker. For tissue samples and highly degraded samples (autopsy samples), mitochondrial gene-based assays appear to be a promising, more robust alternative to the classical $18 \mathrm{~S}$ rDNA- and $28 \mathrm{~S}$ rDNA-based assays. The rnl marker provides consistent quantification of fungal burden in murine organs. Differing from nuclear markers, mitochondrial markers have the unique capacity to indicate growth stage, which could also be demonstrated in clinical specimen mimics. Other non-nuclear markers deserve consideration because they could improve the capacity to effectively diagnose fungal infections at the species level.

Supplementary Materials: The following are available online at http://www.mdpi.com/2309-608X/5/4/98/s1. Table S1: Reference strain set. Table S2: Strain set. Table S3: Single nucleotide polymorphisms (SNPs) found in the $276 \mathrm{bp}$ rnl gene fragment. Nucleotide positions are according the consensus rnl sequence after alignment and trimming of sequences. Results are based on 82 isolates. The SNPs not covered by the real-time PCR-HRM are depicted in light grey. Table S4: Results of rnl real-time PCR-HRM (b) and ITS sequencing (a). $10^{9}$ Mucorales isolates from our strain collection (Tables S1 and S2) were tested and identity was compared. For of rnl real-time PCR-HRM the following parameters are reported: identity, percentage confidence range (c), melting temperature $(\mathrm{Tm})$ range, average, and respective standard deviations are provided. Table S5: Standard deviations of standard curves displayed in Figure 6. Figure S1: Results for the HRM analysis of non-targeted Mucorales species (Mucor racemosus, Phycomyces blakesleeanus, Cunninghamella bertholletiae, and Rhizomucor pusillus) are shown together with the melt profiles of species of interest (Mucor circinelloides, Lichtheimia corymbifera species complex, Rhizopus arrhizus, and Rhizopus microsporus). The experiments were performed to rule out overlapping melt curve profile with other Mucorales species. Melt profiles were computed with Precision Melt Analysis software v 1.2. (A) The areas shaded in green and in red are the pre- and post-melt regions, respectively; the raw melt curves are depicted, before normalization, showing the melt profiles for the positive Mucorales controls and the five other Mucorales, all in different colors; (B) different shapes of melt curves, and subsequently different cluster assignment. $M$. circinelloides was set as reference for automatic clustering. (C) Percent confidence for automatic clustering of the five other Mucorales and respective melt temperatures. Figure S2: Cross reactivity testing of human pathogenic fungi. (A) Amplification plots for four positive control Mucorales DNAs and DNA samples of fungal pathogens other than Mucorales species; one replicate of the Candida glabrata isolate shows amplification after 38 cycles, while one of the 2 replicates of the Aspergillus fumigatus sample and one of the no template controls (NTC) show the same after 39 cycles. (B) Melt peaks for the same samples as (A); the peak for Rhizopus microsporus is depicted in dark green, for Rhizopus arrhizus in salmon, Lichtheimia corymbifera species complex in light green, and Mucor 
circinelloides is colored in light blue; the other fungal organisms exhibit no melt peak and these plots are colored in black. $(C, D)$ The results observed for the high-resolution melt analysis step processed by using the Precision Melt Analysis ${ }^{\mathrm{TM}}$ software v 1.2. (C) The areas shaded in green and in red are the pre- and post-melt regions, respectively; the raw melt curves are depicted, before normalization, showing the melt curves generated for the positive Mucorales controls in colors, and the black lines shown in the graph represent the plots for the non-Mucorales organisms, for which no melt curves are observed. (D) Depicts a typical difference curve for the four Mucorales positive controls analyzed, by using as reference cluster the melt profile generated for $M$. circinelloides. Figure S3: Amplification plots and respective melt peaks obtained for the serial dilution of 106 to $10-1$ conidia spiked in human whole blood samples for defining limit of detection (LoD). The strain R. arrhizus KOG-D3 was used for the spiking experiment. (A) Amplification plots show a positive amplification until the lowest tested concentration (0.1 conidia/PCR reaction), at an average Ct of 36.98. (B) Respective melt peaks are also shown to be linear until the same concentration. Figure S4: Limit of detection (LoD) of rnl real-time PCR-HRM for EDTA-treated human whole blood samples spiked with mucoralean DNA. Range of linearity, trend line with coefficient of determination and linear equation, as well as Ct values for the corresponding dilution steps are shown for (A) L. corymbifera, (B) R. arrhizus, (C) M. circinelloides, (D) L. ramosa, and (E) R. microsporus. Green shaded boxes indicated the level of linearity of the curve that enables the values $R^{2}$ to be calculated. LoD is marked as the right margin of the green box. Figure S5: Divergence in real-time PCR Ct values observed by rnl marker and tef housekeeping gene marker. Growth stages of (A) spores, (B) germlings, and (C) hyphae were determined using a ten-fold dilution series of fungal DNA (\% of total DNA concentration of $10 \mathrm{ng} / \mu \mathrm{L}$ ) in EDTA-treated human whole-blood-spiked samples. Ranges and mean values are given as overall results for the species Lichtheimia spp. complex, R. arrhizus, R. microsporus, and M. circinelloides.

Author Contributions: Conceptualization, study design, interpretation, writing-original draft preparation, supervision, M.L.; methodology, experiments, writing-part of original draft preparation, analysis, R.C.; methodology, experiments, writing-part of original draft preparation, analysis, L.M.; methodology, experiments, writing - part of original draft preparation, analysis, K.R.; experiments, T.L.; supervision, project administration, funding acquisition, writing-review and editing, C.L.-F.; provision of animal organs, writing-review and editing, C.S. and G.R.; provision of strains, writing-review and editing, A.A.-I. and R.A.; provision of pathology samples, writing-part of original draft preparation, J.P.

Funding: CD laboratory: This research was funded by the Christian Doppler Laboratory for fungal infections.

Acknowledgments: The authors want to acknowledge Bettina Sartori for technical assistance and administrative support.

Conflicts of Interest: The authors declare no conflict of interest. The funder had no role in the design of the study; in the collection, analyses, or interpretation of data; in the writing of the manuscript, or in the decision to publish the results.

\section{References}

1. Hibbett, D.S.; Binder, M.; Bischoff, J.F.; Blackwell, M.; Cannon, P.F.; Eriksson, O.E.; Huhndorf, S.; James, T.; Kirk, P.M.; Lücking, R.; et al. A higher-level phylogenetic classification of the fungi. Mycol. Res. 2007, 111, 509-547. [CrossRef] [PubMed]

2. Gleissner, B.; Schilling, A.; Anagnostopolous, I.; Siehl, I.; Thiel, E. Improved outcome of zygomycosis in patients with hematological diseases? Leuk. Lymphoma 2004, 45, 1351-1360. [CrossRef] [PubMed]

3. Kontoyiannis, D.P.; Lewis, R.E.; Lortholary, O.; Spellberg, B.; Petrikkos, G.; Roilides, E.; Ibrahim, A.; Walsh, T.J. Future directions in mucormycosis research. Clin. Infect. Dis. 2012, 54, S79-S85. [CrossRef] [PubMed]

4. Boucher, H.W.; Groll, A.H.; Chiou, C.C.; Walsh, T.J. Newer systemic antifungal agents. Drugs 2004, 64, 1997-2020. [CrossRef] [PubMed]

5. Millon, L.; Scherer, E.; Rocchi, S.; Bellanger, A.-P. Molecular strategies to diagnose mucormycosis. J. Fungi 2019, 5, 24. [CrossRef] [PubMed]

6. Dannaoui, E. Molecular tools for identification of zygomycetes and the diagnosis of zygomycosis. Clin. Microbiol. Infect. 2009, 15, 66-70. [CrossRef] [PubMed]

7. Richardson, M.D.; Cuenca-Estrella, M.; Maertens, J. An introduction to current standards of care in invasive fungal disease. J. Antimicrob. Chemother. 2019, 74, ii2. [CrossRef] [PubMed]

8. Paiva, J.-A.; Pereira, J.M. Biomarkers of fungal lung infection. Curr. Opin. Infect. Dis. 2019, 32, 136-142. [CrossRef]

9. Normand, A.-C.; Cassagne, C.; Gautier, M.; Becker, P.; Ranque, S.; Hendrickx, M.; Piarroux, R. Decision criteria for maldi-tof ms-based identification of filamentous fungi using commercial and in-house reference databases. BMC Microbiol. 2017, 17, 25. [CrossRef] 
10. Mery, A.; Sendid, B.; François, N.; Cornu, M.; Poissy, J.; Guerardel, Y.; Poulain, D. Application of mass spectrometry technology to early diagnosis of invasive fungal infections. J. Clin. Microbiol. 2016, 54, 2786-2797. [CrossRef]

11. Hata, D.J.; Buckwalter, S.P.; Pritt, B.S.; Roberts, G.D.; Wengenack, N.L. Real-time pcr method for detection of zygomycetes. J. Clin. Microbiol. 2008, 46, 2353-2358. [CrossRef] [PubMed]

12. Baldin, C.; Soliman, S.S.M.; Jeon, H.H.; Alkhazraji, S.; Gebremariam, T.; Gu, Y.; Bruno, V.M.; Cornely, O.A.; Leather, H.L.; Sugrue, M.W.; et al. Pcr-based approach targeting Mucorales-specific gene family for diagnosis of mucormycosis. J. Clin. Microbiol. 2018, 56, e00746-18. [CrossRef] [PubMed]

13. Gebremariam, T.; Liu, M.; Luo, G.; Bruno, V.; Phan, Q.T.; Waring, A.J.; Edwards, J.E., Jr.; Filler, S.G.; Yeaman, M.R.; Ibrahim, A.S. Coth3 mediates fungal invasion of host cells during mucormycosis. J. Clin. Investig. 2014, 124, 237-250. [CrossRef] [PubMed]

14. Schwarz, P.; Bretagne, S.; Gantier, J.-C.; Garcia-Hermoso, D.; Lortholary, O.; Dromer, F.; Dannaoui, E. Molecular identification of zygomycetes from culture and experimentally infected tissues. J. Clin. Microbiol. 2006, 44, 340-349. [CrossRef] [PubMed]

15. Merheb, M.; Matar, R.; Hodeify, R.; Siddiqui, S.S.; Vazhappilly, C.G.; Marton, J.; Azharuddin, S.; AL Zouabi, H. Mitochondrial DNA, a powerful tool to decipher ancient human civilization from domestication to music, and to uncover historical murder cases. Cells 2019, 8, 433. [CrossRef] [PubMed]

16. Shokolenko, I.; LeDoux, S.; Wilson, G.; Alexeyev, M. Mitochondrial DNA damage, repair, degradation and experimental approaches to studying these phenomena. In DNA Repair-on the Pathways to Fixing DNA Damage and Errors; IntechOpen: London, UK, 2011.

17. Lackner, M.; Caramalho, R.; Lass-Flörl, C. Laboratory diagnosis of mucormycosis: Current status and future perspectives. Future Microbiol. 2014, 9, 683-695. [CrossRef] [PubMed]

18. Caramalho, R.; Maurer, E.; Binder, U.; Araújo, R.; Dolatabadi, S.; Lass-Flörl, C.; Lackner, M. Etest cannot be recommended for in vitro susceptibility testing of Mucorales. Antimicrob. Agents Chemother. 2015, 59, 3663-3665. [CrossRef] [PubMed]

19. Wöstemeyer, J. Strain-dependent variation in ribosomal DNA arrangement in absidia glauca. Eur. J. Biochem. 1985, 146, 443-448. [CrossRef] [PubMed]

20. White, T.J.; Bruns, T.; Lee, S.; Taylor, J. Pcr Protocols Amplification and Direct Sequencing of Fungal Ribosomal Rna Genes for Phylogenetics; Elsevier: Amsterdam, The Netherland, 1990.

21. Möller, E.M.; Bahnweg, G.; Sandermann, H.; Geiger, H.H. A simple and efficient protocol for isolation of high molecular weight DNA from filamentous fungi, fruit bodies, and infected plant tissues. Nucleic Acids Res. 1992, 20, 6115-6116. [CrossRef] [PubMed]

22. Caramalho, R. Mucorales Identification and Detection of Azole Resistance. Ph.D. Thesis, Medical University Innsbruck, Innrain, Austria, 2017.

23. Prakash, H.; Chakrabarti, A. Global epidemiology of mucormycosis. J. Fungi 2019, 5, 26. [CrossRef] [PubMed]

24. Seif, E.; Leigh, J.; Liu, Y.; Roewer, I.; Forget, L.; Lang, B.F. Comparative mitochondrial genomics in zygomycetes: Bacteria-like rnase $\mathrm{p}$ rnas, mobile elements and a close source of the group i intron invasion in angiosperms. Nucleic Acids Res. 2005, 33, 734-744. [CrossRef] [PubMed]

25. Leung, S.-Y.; Huang, Y.; Lau, S.K.P.; Woo, P.C.Y. Complete mitochondrial genome sequence of lichtheimia ramosa (syn. Lichtheimia hongkongensis). Genome Announc. 2014, 2, e00644-14. [CrossRef] [PubMed]

26. Serris, A.; Danion, F.; Lanternier, F. Disease entities in mucormycosis. J. Fungi 2019, 5, 23. [CrossRef] [PubMed]

27. Klimko, N.; Khostelidi, S.; Shadrivova, O.; Volkova, A.; Popova, M.; Uspenskaya, O.; Shneyder, T.; Bogomolova, T.; Ignatyeva, S.; Zubarovskaya, L. Contrasts between mucormycosis and aspergillosis in oncohematological patients. Med. Mycol. 2019, 57, S138-S144. [CrossRef] [PubMed]

28. Halliday, C.L.; Chen, S.C.A.; Kidd, S.E.; van Hal, S.; Chapman, B.; Heath, C.H.; Lee, A.; Kennedy, K.J.; Daveson, K.; Sorrell, T.C.; et al. Antifungal susceptibilities of non-aspergillus filamentous fungi causing invasive infection in australia: Support for current antifungal guideline recommendations. Int. J. Antimicrob. Agents 2016, 48, 453-458. [CrossRef] [PubMed]

29. Dimopoulos, G.; Frantzeskaki, F.; Poulakou, G.; Armaganidis, A. Invasive aspergillosis in the intensive care unit. Ann. N. Y. Acad. Sci. 2012, 1272, 31-39. [CrossRef] [PubMed] 
30. Cornely, O.A.; Arikan-Akdagli, S.; Dannaoui, E.; Groll, A.H.; Lagrou, K.; Chakrabarti, A.; Lanternier, F.; Pagano, L.; Skiada, A.; Akova, M.; et al. Escmid† and ecmm joint clinical guidelines for the diagnosis and management of mucormycosis 2013. Clin. Microbiol. Infect. 2014, 20, 5-26. [CrossRef] [PubMed]

31. Lackner, M.; Lass-Flörl, C. Commercial molecular tests for fungal diagnosis from a practical point of view. In Human Fungal Pathogen Identification; Springer: Berlin, Germany, 2017; pp. 85-105.

32. Tacke, D.; Koehler, P.; Markiefka, B.; Cornely, O.A. Our 2014 approach to mucormycosis. Mycoses 2014, 57, 519-524. [CrossRef]

33. Irinyi, L.; Lackner, M.; de Hoog, G.S.; Meyer, W. DNA barcoding of fungi causing infections in humans and animals. Fungal Biol. 2016, 120, 125-136. [CrossRef]

34. Bernal-Martínez, L.; Buitrago, M.J.; Castelli, M.V.; Rodriguez-Tudela, J.L.; Cuenca-Estrella, M. Development of a single tube multiplex real-time pcr to detect the most clinically relevant mucormycetes species. Clin. Microbiol. Infect. 2013, 19, E1-E7. [CrossRef]

35. Dannaoui, E.; Schwarz, P.; Slany, M.; Loeffler, J.; Jorde, A.T.; Cuenca-Estrella, M.; Hauser, P.M.; Shrief, R.; Huerre, M.; Freiberger, T.; et al. Molecular detection and identification of zygomycetes species from paraffin-embedded tissues in a murine model of disseminated zygomycosis: A collaborative european society of clinical microbiology and infectious diseases (escmid) fungal infection study group (efisg) evaluation. J. Clin. Microbiol. 2010, 48, 2043-2046. [PubMed]

36. Hrncirova, K.; Lengerova, M.; Kocmanova, I.; Racil, Z.; Volfova, P.; Palousova, D.; Moulis, M.; Weinbergerova, B.; Winterova, J.; Toskova, M.; et al. Rapid detection and identification of mucormycetes from culture and tissue samples by use of high-resolution melt analysis. J. Clin. Microbiol. 2010, 48, 3392-3394. [CrossRef] [PubMed]

37. Hsiao, C.R.; Huang, L.; Bouchara, J.-P.; Barton, R.; Li, H.C.; Chang, T.C. Identification of medically important molds by an oligonucleotide array. J. Clin. Microbiol. 2005, 43, 3760-3768. [CrossRef] [PubMed]

38. Lengerova, M.; Racil, Z.; Hrncirova, K.; Kocmanova, I.; Volfova, P.; Ricna, D.; Bejdak, P.; Moulis, M.; Pavlovsky, Z.; Weinbergerova, B.; et al. Rapid detection and identification of mucormycetes in bronchoalveolar lavage samples from immunocompromised patients with pulmonary infiltrates by use of high-resolution melt analysis. J. Clin. Microbiol. 2014, 52, 2824-2828. [CrossRef] [PubMed]

39. Millon, L.; Larosa, F.; Lepiller, Q.; Legrand, F.; Rocchi, S.; Daguindau, E.; Scherer, E.; Bellanger, A.-P.; Leroy, J.; Grenouillet, F. Quantitative polymerase chain reaction detection of circulating DNA in serum for early diagnosis of mucormycosis in immunocompromised patients. Clin. Infect. Dis. 2013, 56, e95-e101. [CrossRef] [PubMed]

40. Nagao, K.; Ota, T.; Tanikawa, A.; Takae, Y.; Mori, T.; Udagawa, S.-I.; Nishikawa, T. Genetic identification and detection of human pathogenic rhizopus species, a major mucormycosis agent, by multiplex pcr based on internal transcribed spacer region of rrna gene. J. Dermatol. Sci. 2005, 39, 23-31. [CrossRef] [PubMed]

41. Nilsson, R.H.; Kristiansson, E.; Ryberg, M.; Hallenberg, N.; Larsson, K.-H. Intraspecific its variability in the kingdom fungi as expressed in the international sequence databases and its implications for molecular species identification. Evol. Bioinform. Online 2008, 4, 193-201. [CrossRef]

42. Woo, P.C.Y.; Leung, S.-Y.; To, K.K.W.; Chan, J.F.W.; Ngan, A.H.Y.; Cheng, V.C.C.; Lau, S.K.P.; Yuen, K.-Y. Internal transcribed spacer region sequence heterogeneity in rhizopus microsporus: Implications for molecular diagnosis in clinical microbiology laboratories. J. Clin. Microbiol. 2010, 48, 208-214. [CrossRef]

43. Santamaria, M.; Vicario, S.; Pappadà, G.; Scioscia, G.; Scazzocchio, C.; Saccone, C. Towards barcode markers in fungi: An intron map of ascomycota mitochondria. BMC Bioinform. 2009, 10, S15. [CrossRef]

44. SEIFERT, K.A. Progress towards DNA barcoding of fungi. Mol. Ecol. Resour. 2009, 9, 83-89. [CrossRef]

45. Garcia-Hermoso, D.; Hoinard, D.; Gantier, J.-C.; Grenouillet, F.; Dromer, F.; Dannaoui, E. Molecular and phenotypic evaluation of lichtheimia corymbifera (formerly absidia corymbifera) complex isolates associated with human mucormycosis: Rehabilitation of L. Ramosa. J. Clin. Microbiol. 2009, 47, 3862-3870. [CrossRef] [PubMed]

46. Hjelmsø, M.H.; Hansen, L.H.; Bælum, J.; Feld, L.; Holben, W.E.; Jacobsen, C.S. High-resolution melt analysis for rapid comparison of bacterial community compositions. Appl. Environ. Microbiol. 2014, 80, 3568-3575. [CrossRef] [PubMed]

47. Miller, M.; Zorn, J.; Brielmeier, M. High-resolution melting curve analysis for identification of pasteurellaceae species in experimental animal facilities. PLOS ONE 2015, 10, e0142560. [CrossRef] [PubMed] 
48. Chua, K.H.; Lim, S.C.; Ng, C.C.; Lee, P.C.; Lim, Y.A.L.; Lau, T.P.; Chai, H.C. Development of high resolution melting analysis for the diagnosis of human malaria. Sci. Rep. 2015, 5, 15671. [CrossRef] [PubMed]

49. Arancia, S.; Sandini, S.; De Bernardis, F.; Fortini, D. Rapid, simple, and low-cost identification of candida species using high-resolution melting analysis. Diagn. Microbiol. Infect. Dis. 2011, 69, 283-285. [CrossRef] [PubMed]

50. Didehdar, M.; Khansarinejad, B.; Amirrajab, N.; Shokohi, T. Development of a high-resolution melting analysis assay for rapid and high-throughput identification of clinically important dermatophyte species. Mycoses 2016, 59, 442-449. [CrossRef] [PubMed]

51. Duyvejonck, H.; Cools, P.; Decruyenaere, J.; Roelens, K.; Noens, L.; Vermeulen, S.; Claeys, G.; Decat, E.; Van Mechelen, E.; Vaneechoutte, M. Validation of high resolution melting analysis (hrm) of the amplified its2 region for the detection and identification of yeasts from clinical samples: Comparison with culture and maldi-tof based identification. PLOS ONE 2015, 10, e0132149.

52. Gago, S.; Zaragoza, Ó.; Cuesta, I.; Rodríguez-Tudela, J.L.; Cuenca-Estrella, M.; Buitrago, M.J. High-resolution melting analysis for identification of the cryptococcus neoformans-cryptococcus gattii complex. J. Clin. Microbiol. 2011, 49, 3663-3666. [CrossRef] [PubMed]

53. Nemcova, E.; Cernochova, M.; Ruzicka, F.; Malisova, B.; Freiberger, T.; Nemec, P. Rapid identification of medically important candida isolates using high resolution melting analysis. PLoS ONE 2015, 10, e0116940. [CrossRef]

54. Guo, N.; Wang, B.; Ren, W.; Liu, M.; Chu, M.; Meng, D.; Yao, L.; Xue, W. Application of pcr and high-resolution melting for rapid identification of yeasts routinely isolated in a clinical microbiology laboratory. Ann. Clin. Lab. Sci. 2015, 45, 680-685.

55. Goldschmidt, P.; Degorge, S.; Che Sarria, P.; Benallaoua, D.; Semoun, O.; Borderie, V.; Laroche, L.; Chaumeil, C. New strategy for rapid diagnosis and characterization of fungal infections: The example of corneal scrapings. PLoS ONE 2012, 7, e37660. [CrossRef] [PubMed]

56. Bialek, R.; Konrad, F.; Kern, J.; Aepinus, C.; Cecenas, L.; Gonzalez, G.M.; Just-Nübling, G.; Willinger, B.; Presterl, E.; Lass-Flörl, C.; et al. Pcr based identification and discrimination of agents of mucormycosis and aspergillosis in paraffin wax embedded tissue. J. Clin. Pathol. 2005, 58, 1180-1184. [CrossRef] [PubMed]

57. Millon, L.; Herbrecht, R.; Grenouillet, F.; Morio, F.; Alanio, A.; Letscher-Bru, V.; Cassaing, S.; Chouaki, T.; Kauffmann-Lacroix, C.; Poirier, P.; et al. Early diagnosis and monitoring of mucormycosis by detection of circulating DNA in serum: Retrospective analysis of 44 cases collected through the french surveillance network of invasive fungal infections (ressif). Clin. Microbiol. Infect. 2016, 22, 810-e1. [CrossRef] [PubMed]

58. Bellanger, A.-P.; Berceanu, A.; Rocchi, S.; Valot, B.; Fontan, J.; Chauchet, A.; Belin, N.; Scherer, E.; Deconinck, E.; Navellou, J.-C.; et al. Development of a quantitative pcr detecting cunninghamella bertholletiae to help in diagnosing this rare and aggressive mucormycosis. Bone Marrow Transplant. 2018, 53, 1180-1183. [CrossRef] [PubMed]

59. Springer, J.; Lackner, M.; Ensinger, C.; Risslegger, B.; Morton, C.O.; Nachbaur, D.; Lass-Flörl, C.; Einsele, H.; Heinz, W.J.; Loeffler, J. Clinical evaluation of a Mucorales-specific real-time pcr assay in tissue and serum samples. J. Med. Microbiol. 2016, 65, 1414-1421. [CrossRef]

60. Jornayvaz, F.R.; Shulman, G.I. Regulation of mitochondrial biogenesis. Essays Biochem. 2010, 47, 69-84. [CrossRef] [PubMed]

61. Perfect, J.R. Fungal diagnosis: How do we do it and can we do better? Curr. Med. Res. Opin. 2013, 29 , 3-11. [CrossRef]

(C) 2019 by the authors. Licensee MDPI, Basel, Switzerland. This article is an open access article distributed under the terms and conditions of the Creative Commons Attribution (CC BY) license (http://creativecommons.org/licenses/by/4.0/). 